\title{
LA PROTECCIÓN DEL TERCERO HIPOTECARIO ANTE LA CESIÓN POR UN SOLO CÓNYUGE DE UN BIEN DE LA COMUNIDAD POSGANANCIAL Y HEREDITARIA A CAMBIO DE ALIMENTOS
}

\author{
The protection of the acquirer against the sale \\ of a good belonging to the post-marriage community \\ and hereditary community made by a single spouse \\ in exchange for assistance
}

\author{
MARGARITA CASTILLA BAREA \\ Universidad de Cádiz \\ margarita.castilla@gm.uca.es
}

Cómo citar/Citation

Castilla Barea, M. (2019).

La protección del tercero hipotecario ante la cesión por un solo cónyuge de un bien de la comunidad posganancial y hereditaria a cambio de alimentos.

Derecho Privado y Constitución, 35, 125-167.

doi: https://doi.org/10.18042/cepc/dpc.35.04

(Recepción: 09/08/2019; aceptación tras revisión: 21/10/2019; publicación: 29/11/2019)

\section{Resumen}

Este artículo analiza las diversas soluciones que ofrecen la doctrina científica y la jurisprudencia a la cuestión de la calificación jurídica que debe otorgarse a los actos y contratos de finalidad traslativa del dominio realizados por el cónyuge supérstite sobre bienes de la comunidad posganancial sin contar con el consentimiento del resto de coherederos del premuerto. La decisión acerca de su nulidad o validez determinará en muchos casos que el tercero adquirente en virtud de uno de estos actos o contratos pueda invocar la protección de la fe pública registral del art. $34 \mathrm{LH}$, para cuya aplicación se requiere, además, que el negocio celebrado sea oneroso y la buena fe del adquirente. El alcance de estas cuestiones y requisitos se analiza al hilo del caso concreto enjuiciado por la Sentencia del Tribunal Supremo de 29 de noviembre de 2018. 


\section{Palabras clave}

Venta de cosa común por un comunero; nulidad; validez; fe pública registral; buena fe del tercero hipotecario.

Abstract

This article analyzes the various solutions offered by scientific doctrine and jurisprudence to the issue of legal qualification that must be granted to acts and contracts for the purpose of transferring ownership of a good belonging to the post-marriage community made by the surviving spouse without the consent of the rest of the heirs of the previously deceased spouse. The decision about its nullity or validity will determine in many cases that the third party acquiring by virtue of one of these acts or contracts may invoke the protection of the Real Estate Registry because of art. $34 \mathrm{LH}$. Its application also requires that the business held be expensive and the good faith of the acquirer. The scope of these issues and requirements are analyzed in line with the specific case prosecuted by the Supreme Court Judgment of November 29, 2018.

\section{Keywords}

Sale of common thing by a commoner; nullity; validity; public faith of the Real Estate Registry; good faith of the acquirer. 


\section{SUMARIO}

I. PROEMIO: REFLEXIONES AL HILO DE UN CASO REAL. II. LOS PRESUPUESTOS PARA LA EFICACIA DEL PRINCIPIO DE FE PÚBLICA REGISTRAL: BREVE REFERENCIA GENERAL Y DETERMINACIÓN DE LOS QUE SE DEBATEN EN LA SENTENCIA DE AUTOS. III. LA NECESIDAD DE UN NEGOCIO JURÍDICO VÁLIDO: EL JUEGO COMBINADO DE LOS ARTÍCULOS 33 Y 34 LH: 1. Origen y tipología de la inexactitud registral relativa al derecho de la madre otorgante. 2. La impugnación de la validez del negocio jurídico base de la transmisión de derechos a las adquirentes demandadas: 2.1. La irrelevancia de la naturaleza jurídica propia del contrato celebrado a los efectos de determinar su validez en el caso de autos. 2.2. La vía de impugnación elegida por el actor: atacar la validez del negocio por constituir un acto de disposición de la cosa común realizado individualmente y en nombre propio por uno solo de los partícipes. Planteamiento del problema. 2.3. La pretensión esgrimida por el actor: el acto de disposición del bien de la comunidad posganancial realizado en solitario y en su propio nombre por la viuda es nulo de pleno derecho. 2.4. La decisión del Tribunal Supremo: el acto de disposición del bien de la comunidad posganancial realizado en solitario y en su propio nombre por la viuda es válido, al constituir un supuesto de venta de cosa (parcialmente) ajena. 2.5. La conveniencia de una reforma legal y la necesidad de unificación de la doctrina jurisprudencial respecto a la calificación jurídica que ha de darse a este tipo de actos. IV. EL CONTRATO DE ALIMENTOS COMO TÍTULO APTO PARA LA TRANSMISIÓN DEL DOMINIO DE CARÁCTER ESENCIALMENTE ONEROSO. V. LA BUENA FE DEL TERCERO HIPOTECARIO. SU APRECIACIÓN EN EL CASO DE AUTOS: 1. EI concepto de buena fe registral. 2. La presunción de la buena fe registral. Actividad probatoria. 3. La buena fe de las adquirentes en el caso de autos. BibLIOGRAFía.

\section{PROEMIO: REFLEXIONES AL HILO DE UN CASO REAL}

En ocasiones, un nuevo pronunciamiento del Tribunal Supremo pone de manifiesto la trascendencia dogmática y práctica de cuestiones jurídicas que, no resueltas definitivamente por el legislador en un sentido concreto, vuelven a plantearse ante los tribunales con una cierta cadencia y que, precisamente por su enjundia y calado técnico, suscitan en los autores interpretaciones y 
propuestas de solución diversas y originan doctrinas jurisprudenciales varias que conviven, o se suceden, en el devenir de los tiempos.

Así ha ocurrido con la Sentencia del Tribunal Supremo de 29 de noviembre de $2018^{1}$, que muestra la vigencia y el interés constante que pueden suscitar algunas de esas cuestiones jurídicas que, por la atención recurrente que cada tanto les dispensan la jurisprudencia y la doctrina científica, suelen tildarse de "clásicas» y que, en esta ocasión, orbitan en torno a la calificación jurídica que, en general, corresponde a la venta de la cosa común sin el consentimiento de todos los partícipes y, más concretamente, a la calificación que merecen los actos dispositivos realizados por el cónyuge supérstite sobre bienes de la comunidad posganancial sin contar con el consentimiento del resto de coherederos del premuerto. De la respuesta que se otorgue a ese interrogante, que oscila entre la validez y la nulidad de los actos de tal naturaleza, dependerá la aplicabilidad del art. $34 \mathrm{LH}$, que, por su parte, plantea otras cuestiones de hondo interés y de amplio alcance, como el modo en que se cohonesta ese precepto con el art. $33 \mathrm{LH}$, o en qué consiste la buena fe que aquel precepto exige al adquirente de un bien inmueble para otorgarle protección como tercero hipotecario. Al hilo del caso concreto resuelto en la meritada sentencia, adquiere también importancia la caracterización del contrato de alimentos regulado en los arts. 1791 y ss. del Código Civil, en cuanto título apto para adquirir el dominio merced al propio art. $34 \mathrm{LH}$, como un contrato gratuito u oneroso.

El dictado de esta sentencia, que muestra la actualidad de las materias aludidas, nos brinda la oportunidad de revisar el status quaestionis de los dilemas jurídicos que se han enunciado en el párrafo anterior, teniendo como telón de fondo para enfocarlos y delimitarlos los hechos que concretamente tuvieron lugar en el caso de autos.

En cuanto al conflicto que dio origen al litigio, puede decirse que la historia jurídica de la finca que enfrenta a los hermanos contendientes presenta alguna peculiaridad interesante: sus padres, D. Eliseo y D. ${ }^{a}$ Carmela, contrajeron matrimonio en 1944 en régimen de gananciales. En 1955 se les adjudicó un piso construido por la Obra Sindical del Hogar, con precio aplazado y acceso diferido a la propiedad, sin que entonces se otorgase escritura pública alguna del referido negocio. Del matrimonio nacieron cinco hijos que se criaron en la vivienda. En 1971 falleció el marido y padre y catorce años más tarde, en 1985, la Comunidad Valenciana, una vez comprobada la amor-

1 Sentencia del Tribunal Supremo (Sala de lo Civil, Sección 1.a) núm. 672/2018, de 29 de noviembre (RJ 2018, 5395), de la que es ponente la Excma. Sra. M.a Ángeles Parra Lucán. 
tización total del valor del piso, procedió a otorgar escritura de compraventa a favor de la viuda. La escritura se inscribió en el Registro de la Propiedad el 21 de diciembre de 1985.

Veintiún años más tarde, el 1 de marzo de 2007, D. ${ }^{a}$ Carmela celebró con dos de sus hijas, D. ${ }^{a}$ Constanza y D. ${ }^{a}$ Delfina, un contrato de alimentos en cuya virtud aquella cedía la nuda propiedad del inmueble en cuestión por mitades indivisas a sus dos hijas, a cambio de que estas le proporcionaran el sustento, habitación, vestido y asistencia médica que precisara hasta el fin de sus días. La escritura pública de otorgamiento del contrato de alimentos fue inscrita en el Registro de la Propiedad dos meses más tarde, en mayo de 2007. El citado contrato desplegó sus efectos hasta la muerte de D. ${ }^{a}$ Carmela, en $2014^{2}$. Fue entonces cuando otro de sus hijos demandó a las hermanas, alimentantes de su madre y cesionarias del inmueble, y al resto de herederos de sus difuntos padres ${ }^{3}$, solicitando que se declarase el carácter ganancial de la vivienda, con la consiguiente rectificación de la inscripción registral de 1985 en la que figuraba solo su madre; que se declarase igualmente la nulidad del contrato de alimentos celebrado entre esta y sus dos hermanas, y, consiguientemente, que se procediese a la cancelación de esta segunda inscripción registral $^{4}$.

Los órganos de instancia acogieron las pretensiones del demandante al considerar que, en efecto, el bien tenía naturaleza ganancial y que, por tanto, la madre no podía disponer del piso sin contar con el consentimiento de todos sus hijos, en cuanto que herederos, como ella misma, de su marido fallecido. Tres son los argumentos en que se basan las sentencias de instancia para negar a las demandadas la tutela que proporciona el art. $34 \mathrm{LH}$ al tercero hipotecario: se considera que el negocio dispositivo a favor de las hijas fue nulo de pleno derecho y que, por tanto, no se cumple la exigencia de título válido; se califica el contrato de alimentos como un negocio gratuito y, finalmente, se niega que las hermanas cesionarias tuvieran la buena fe que el precepto exige,

2 La fecha de la muerte de la madre del actor no consta en la sentencia de casación; el dato se ha extraído de la resolución a la que casa: Sentencia de la Audiencia Provincial de Alicante (Sección 6.a), núm. 94/2016, de 14 abril (JUR, 2016, 148112), FJ 3.

3 El actor dirigió su demanda contra sus tres hermanos vivos y contra sus tres sobrinos, como sucesores de otro de los hermanos que ya había fallecido, si bien tan solo las dos hermanas cesionarias prosiguieron el litigio; los demás demandados fueron declarados en rebeldía.

4 Aunque el contrato celebrado entre madre e hijas confería a estas tan solo la nuda propiedad de la vivienda, las hermanas demandadas habían consolidado ya la plena propiedad del inmueble en el momento de interponerse la demanda origen del litigio, dado que el usufructo que se reservara su madre se había extinguido a su muerte. 
pues debían conocer el carácter ganancial de la finca en la que habían vivido durante toda su vida.

Así las cosas, llega el caso al Tribunal Supremo, que analiza estos argumentos y casa la sentencia de la Audiencia Provincial al entender, contrariamente a ella, que el negocio dispositivo efectuado en solitario por la viuda es válido; que el contrato de alimentos en que dicho negocio consistió tiene carácter oneroso y no gratuito y que no ha quedado debidamente desvirtuada la presunción de buena fe que asiste a las hermanas adquirentes.

\section{LOS PRESUPUESTOS PARA LA EFICACIA DEL PRINCIPIO DE FE PÚBLICA REGISTRAL: BREVE REFERENCIA GENERAL Y DETERMINACIÓN DE LOS QUE SE DEBATEN EN LA SENTENCIA DE AUTOS}

Como es sabido, el principio de fe pública registral se considera la piedra angular ${ }^{5}$ de nuestro derecho inmobiliario registral y se halla consagrado en el art. $34 \mathrm{LH}$, a cuyo tenor:

El tercero que de buena fe adquiera a título oneroso algún derecho de persona que en el Registro aparezca con facultades para transmitirlo, será mantenido en su adquisición, una vez que haya inscrito su derecho, aunque después se anule o resuelva el del otorgante por virtud de causas que no consten en el mismo Registro.

La buena fe del tercero se presume siempre mientras no se pruebe que conocía la inexactitud del Registro.

Los adquirentes a título gratuito no gozarán de más protección registral que la que tuviere su causante o transferente.

Hay consenso en afirmar que la norma se dirige ante todo a otorgar seguridad al tráfico jurídico, protegiendo en su adquisición a la persona que, confiando en la presunta exactitud de los asientos registrales (ex art. $38 \mathrm{LH}$ ), adquiere el dominio o cualquier otro derecho real sobre bienes inmuebles de quien figura en el propio Registro como titular del derecho mismo y con

5 El carácter central de este principio hipotecario se pone de manifiesto unánimemente por la doctrina con expresiones diversas que apuntan en la misma dirección. Así, entre otros, Domínguez Luelmo (2016: 555) lo califica de «núcleo de nuestro sistema registral», Moralejo Imbernón (2013: 129), de "principio básico o esencial» del sistema publicitario del Registro, y Juárez Torrejón (2016: 130), de «idea nuclear». 
facultades para disponer de él ${ }^{6}$. Para que el adquirente obtenga la máxima protección que puede otorgarle el sistema inmobiliario registral, la ley exige, además de su buena fe, que la adquisición del derecho resulte de la celebración de un negocio jurídico válido y de carácter oneroso y que el accipiens proceda también, por su parte, a inscribir en el Registro el derecho adquirido ${ }^{7}$. A quien se convierte en titular de un derecho real en las condiciones descritas se le denomina "tercero hipotecario»" y será protegido en su adquisición aun cuando después de transitar todo el proceso descrito y por causas que no consten en el Registro de la Propiedad se demuestre que su transmitente no era el verdadero titular del derecho o no podía disponer de él del modo en que lo hizo. La inmunidad de la adquisición del tercero hipotecario consiste en que, en tal caso, no prosperarán contra él las acciones que el verdadero titular del derecho pudiera ejercitar en su contra para recuperar el bien o el derecho adquirido, que permanecerá en el patrimonio del adquirente'; tampoco tendrá que hacer frente a pretensión indemnizatoria alguna ${ }^{10}$.

Pese a la aparente sencillez de este planteamiento, lo cierto es que la concisa formulación que el legislador hizo del principio de fe pública registral en el art. $34 \mathrm{LH}$ ha dado pie a más de una interpretación respecto a su alcance y al sentido que ha de atribuirse a alguna de sus exigencias, sobre todo cuando se pretende su aplicación en determinados supuestos de hecho (venta doble o múltiple, de cosa ajena, del bien común por un condómino, adquisición en venta judicial, etc.). La contundencia de sus consecuencias hace que con alguna frecuencia se planteen litigios en los que las controversias entre los distintos pretendidos titu-

6 Señala García García (1993: 231) que «la clave del artículo 34 LH es la confianza del tercero en la legitimación dispositiva resultante del Registro, es decir, en la apariencia registral derivada del principio de legitimación registral que produce el asiento y que hace que el legislador tome en consideración esta situación para llegar incluso a la protección de las adquisiciones inmobiliarias a non domino». La propensión del precepto a la tutela de la seguridad del tráfico jurídico, por encima de la tutela «estática» de los derechos reales, se destaca como finalidad de la norma también por Juárez Torrejón (2016: 122).

7 Como explicaremos enseguida, la exigencia de que el título sea válido no se explicita en el art. $34 \mathrm{LH}$, sino que se extrae del art. $33 \mathrm{LH}$, que establece que «la inscripción no convalida los actos o contratos que sean nulos con arreglo a las leyes».

8 Es, como indica Domínguez Luelmo (2016: 557), «el destinatario o beneficiario de la fe pública registral».

9 Se habla también de «inatacabilidad», pues, como resume Domínguez Luelmo (2016: 555): «Quien contrata confiando en lo que publica el Registro, aunque este sea inexacto, queda protegido de forma inatacable».

10 En este sentido, véanse Moralejo Imbernón (2013: 133) y la STS de 23 de abril de 2010 (RJ 3548). 
lares de derechos reales se resuelven sobre la base de acreditar en alguno de ellos la concurrencia o no de cuantos requisitos impone la norma, y, en ese proceso, los matices de algunos casos reales han llevado a los tribunales a cuestionarse el sentido del precepto, las reglas para su aplicación y la recta definición de sus presupuestos. En esta tarea se ha afanado también la doctrina científica, que alguna vez ha servido de inspiración para el golpe de timón que en algún aspecto concreto se aprecia en la doctrina jurisprudencial de la Sala Primera del Tribunal Supremo en torno a la aplicación del art. $34 \mathrm{LH}^{11}$.

En el caso enjuiciado por la STS de 29 de noviembre de 2018 (RJ 5395) se debate sobre la concurrencia de tres de los presupuestos de aplicación del art. $34 \mathrm{LH}$ : en primer lugar, la validez del título esgrimido para la adquisición de la propiedad de la otrora vivienda familiar por parte de las hermanas demandadas; en segundo lugar, el carácter oneroso o gratuito del negocio jurídico por el que se les transmitió la nuda propiedad de la finca, y, finalmente, su condición de adquirentes de buena fe. Fuera del debate casacional, por incontrovertidos en el caso, quedaron los extremos que menor litigiosidad suelen acarrear, pues quedaba fuera de toda duda que la madre del actor y de las demandadas rezaba como titular registral en pleno dominio de la finca cedida sin que constara restricción alguna de su poder de disposición y que las recurrentes habían logrado, por su parte, inscribir normalmente su derecho ${ }^{12}$. A cada una de estas cuestiones dedicaremos nuestra atención en los apartados siguientes.

\section{LA NECESIDAD DE UN NEGOCIO JURÍDICO VÁLIDO: EL JUEGO COMBINADO DE LOS ARTÍCULOS 33 Y 34 LH}

La exigencia de que la adquisición del tercero hipotecario traiga causa de un negocio jurídico válido resulta de la interpretación conjunta de los arts. 33 y $34 \mathrm{LH}$, aunque tiene su base literal más directa en el primero de estos preceptos, que determina que «[l]a inscripción no convalida los actos o contratos que sean nulos con arreglo a las leyes» ${ }^{13}$, y ha sido confirmada por la juris-

11 Así ha ocurrido, por ejemplo, en lo tocante a la calificación jurídica de la venta de cosa ajena, cuestión en la que la jurisprudencia acogió las tesis previamente formuladas por un sector de la doctrina que abogaba por su validez obligacional, al considerar que la falta de poder de disposición del tradens constituye un vicio o defecto del modo de adquirir y no del título en el que la adquisición se apoya.

12 Requisito este de la inscripción del derecho adquirido que no reunía la parte actora, que invocaba la protección del art. $34 \mathrm{LH}$, en el caso enjuiciado por la STS de 21 de junio de 2011 (RJ 4766). Véase el FJ 2.

13 De la misma opinión, García García (1993: 257). 
prudencia ${ }^{14}$. Ello significa que, por mucho que un asiento registral proclame la vigencia de un derecho adquirido a partir de cierto acto o contrato, si este se declarase ulteriormente nulo o ineficaz, la inscripción no será un obstáculo para la decadencia del derecho que, consiguientemente, provocará también la de la propia inscripción. $\mathrm{O}$, dicho de otro modo: el precepto establece que la inscripción registral carece de efecto sanatorio de la invalidez o ineficacia estructural de los actos o contratos que pueda declararse conforme a las reglas del derecho sustantivo.

Por su parte, parece claro que el ámbito objetivo de aplicación del art. $34 \mathrm{LH}$ es el de las adquisiciones en virtud de un negocio jurídico susceptible de transmitir un derecho del titular registral a otra persona, ya sea mediante su constitución ex novo a partir del derecho que aquel ostenta (como, por ejemplo, cuando el propietario en pleno dominio constituye un derecho de usufructo a favor del adquirente usufructuario), ya sea mediante la transmisión del mismo derecho que ostentaba el titular a un sujeto distinto ${ }^{15}$. En cualquier caso, lo importante es que el negocio jurídico celebrado entre el tradens y el accipiens tenga por finalidad la transmisión de derechos de uno a otro, ya sea constitutiva o derivativa y que la titularidad registral del transmitente ofrezca la apariencia de que posee facultades para disponer de tal derecho.

Si el adquirente contrata con el transmitente confiando en la apariencia de perfecto derecho que proclama la titularidad registral de este último y celebrando con él un negocio que - abstracción hecha de los defectos que dicha titularidad pueda presentar en la realidad extrarregistral - resulta válido ${ }^{16}$, el adquirente será protegido en su adquisición, si se cumplen los demás requisitos del art. $34 \mathrm{LH}$, «aunque después se anule o resuelva» el derecho de su transmitente $^{17}$. El legislador quiere proteger la confianza en la exactitud de los asientos registrales y favorecer la inscripción de los derechos reales sobre inmuebles, para

14 En este sentido, la STS de 25 de octubre de 2004 (RJ 7033), FJ 1.

15 De ahí la precisión de que quedan fuera del ámbito del precepto las adquisiciones por ministerio de la ley y las producidas en virtud de ocupación, accesión y usucapión. En este sentido, véase García García (1993: 253-254).

16 Obviamente, algo debe haber de erróneo, incorrecto o irreal en la información que pregona el Registro de la Propiedad respecto a la titularidad del tradens o a su poder de disposición, pues, en otro caso, y como advierte unánimemente la doctrina, no le sería preciso al adquirente invocar la protección del art. $34 \mathrm{LH}$.

17 De no ser por este inciso del art. $34 \mathrm{LH}$, la nulidad del título del tradens provocaría de suyo la de todos los actos y contratos posteriores que pudieran traer causa del mismo. En consecuencia, el precepto evita que se produzca una cadena de nulidades, inmunizando la adquisición del tercero hipotecario frente a ese efecto. En este sentido, véanse García García (1993: 257) y Juárez Torrejón (2016: 170). 
lo cual hace inmune la adquisición del tercero hipotecario frente a las causas de nulidad, anulabilidad o resolución que pudieran aquejar al derecho de su transmitente, pero sobre la base de que su propia conducta resulta irreprochable, en el sentido de que realizó de buena fe un contrato oneroso con la persona que figuraba como titular registral y procedió por su parte a dar la máxima publicidad a esta situación, inscribiendo a su vez su propio derecho en el Registro de la Propiedad. Si después de culminarse todo este proceso, alguien —el vetus dominus, ya que verus dominus será desde entonces el tercero hipotecario adquirente - reclama y consigue acreditar que el transmitente no era en la realidad extrarregistral titular del derecho en los términos proclamados por el asiento, o que carecía de poder para disponer del derecho del modo en que lo hizo, o que, en definitiva, existía cualquier tipo de inexactitud del Registro ${ }^{18}$, ello provocará las consecuencias que correspondan conforme a derecho en el plano de la relación entre el transmitente (anterior titular registral) y el reclamante que logra acreditar la inexistencia o los defectos del derecho que aquel pretendía ostentar. Podrá incluso lograrse a resultas de ese proceso la nulidad o la rectificación de la inscripción registral que favorecía al tradens, pero nada de ello podrá afectar a la adquisición del tercero hipotecario y, consiguientemente, tampoco a la inscripción lograda a su favor (arg. ex arts. $31 \mathrm{LH}$ y 40 in fine $\mathrm{LH})^{19}$ : este «será mantenido en su adquisición» asumiendo, además, por virtud del art. $34 \mathrm{LH}$, una posición inatacable frente a cualquier pretensión restitutoria o resarcitoria por parte del vetus dominus.

En cambio, si el negocio jurídico celebrado entre el titular registral y su causahabiente estuviese aquejado de algún vicio o defecto estructural que pudiera acarrear su nulidad de pleno derecho o su anulación, o si existiera alguna causa de resolución con eficacia ex tunc que pudiera aquejarle, el adquirente no obtendría la intensa protección que le brinda la fe pública registral y su posición no sería inatacable frente a las reclamaciones del verus dominus; no podría obtener inmunidad frente a las pretensiones legítimas y acertadas de quien demuestre tener un mejor derecho que él, porque la inscripción obteni-

18 Excede de nuestro cometido profundizar en la noción de la inexactitud registral a que se refiere el art. $34 \mathrm{LH}$. Al respecto, puede consultarse la interesante polémica suscitada por la opinión de Méndez González (2018: 28), refutada por Brancós Núñez (2019: 2).

19 El art. 31 LH establece: «La nulidad de las inscripciones de que trata el artículo precedente, no perjudicará el derecho anteriormente adquirido por un tercero protegido con arreglo al artículo treinta y cuatro». Por su parte, dispone el último párrafo del art. $40 \mathrm{LH}$ : «En ningún caso la rectificación del Registro perjudicará los derechos adquiridos por tercero a título oneroso de buena fe durante la vigencia del asiento que se declare inexacto». 
da por el adquirente no convalida los actos o contratos nulos con arreglo a las leyes ex art. $33 \mathrm{LH}$ y en este supuesto el adquirente ni tan siquiera ostenta la condición de «tercero» respecto del negocio viciado ${ }^{20}$.

En consecuencia, del juego combinado de los arts. 33 y $34 \mathrm{LH}$ se extrae que el tercero adquirente en virtud de un negocio jurídico válido que reúna el resto de los requisitos que impone este último precepto será tutelado por la fe pública registral incluso cuando su transmitente careciera de derecho alguno que transmitirle ${ }^{21}$; en cambio, la realidad extrarregistral podrá imponérsele si, aun reuniendo todas las demás exigencias que la norma establece, resulta que el negocio jurídico que celebró con su otorgante estaba aquejado de algún vicio o defecto incompatible con su validez o de alguna causa de resolución impeditiva de su eficacia ${ }^{22}$.

Por cuanto antecede, es lógico que quien pretenda impedir la aplicación del art. $34 \mathrm{LH}$ en un caso concreto combata, si tiene base legal para ello, la concurrencia de todos y cada uno de los requisitos que el precepto impone al adquirente para ser protegido en su adquisición, comenzando por la validez del negocio jurídico celebrado entre el titular registral y el adquirente. Y precisamente esto es lo que intentó — aunque no por todas las vías posibles- el hermano demandante en el caso finalmente resuelto por la STS de 29 de noviembre de 2018 (RJ 5395).

\section{ORIGEN Y TIPOLOGÍA DE LA INEXACTITUD REGISTRAL RELATIVA AL DERECHO DE LA MADRE OTORGANTE}

Según se extrae del relato fáctico asumido en casación, en 1985 se produjo la inscripción del pleno dominio del piso litigioso a favor de la madre del actor y de las hermanas demandadas. En la escritura que accedió al

20 En el mismo sentido, véase García García (1993: 233-234).

21 Es la observación desde esta perspectiva de la relación existente los arts. 33 y 34 LH lo que explica que algunos autores entiendan que el segundo precepto «excepciona» al primero —García García (1993: 257) — o que lo «relativiza» — Juárez Torrejón (2016: 170)-.

22 Así de concluyente se muestra García García (1993: 259): «[...] el contrato en que interviene como parte el tercero hipotecario del artículo 34 ha de ser válido en sí mismo, conforme a lo dispuesto en el artículo $33 \mathrm{LH}$. Cabe precisar que el art. $33 \mathrm{LH}$ no se refiere a la posible resolución del derecho del causante, que, de producirse, obviamente no responde a vicio o defecto estructural alguno del negocio, sino a la presencia de alguna causa de resolución que no constase en el mismo Registro. La inmunidad del tercero hipotecario frente a los efectos de una resolución ex tunc del derecho de su otorgante la establece el propio art. $34 \mathrm{LH}$ y no el $33 \mathrm{LH}$. 
Registro es donde al parecer se origina el error o la omisión respecto a la titularidad de la finca, ya que, si bien el inmueble fue adjudicado en 1955 a ambos esposos - padres de los litigantes_, casados en régimen de gananciales, debido al proceso seguido para su adquisición —que se califica como de acceso diferido a la propiedad, pero viene finalmente a equipararse a una compraventa con precio aplazado y pacto de reserva de dominio- la escritura no se otorgó hasta treinta años después, cuando el marido y padre llevaba ya casi tres lustros fallecido. Por las circunstancias que fueren, lo cierto es que la Administración pública competente otorgó la escritura de propiedad tan solo a favor de la madre de los litigantes, como plena propietaria del piso que años después cedería a sus hijas como capital a cambio de la prestación de alimentos vitalicios, sin que de dicha escritura resultara en ningún momento su carácter de bien ganancial ${ }^{23}$. La fecha del documento público, otorgado en un momento en que la propietaria llevaba ya muchos años viuda, unida a que la adquisición se produce mediante un negocio jurídico de cierta complejidad técnica que podía hacer pensar que la adquisición de la propiedad se culminaba entonces y, en todo caso, el propio contenido literal de la escritura pública inmediatamente inscrita en el Registro de la Propiedad favorecían la apariencia de que la titular registral era propietaria en pleno dominio y con carácter privativo del inmueble inscrito, sin que constara en el propio Registro ninguna otra causa o circunstancia que advirtiera de limitación alguna de sus poderes dispositivos ${ }^{24}$.

23 De ahí que hablemos en el texto de «error u omisión», porque, como es sabido, cabe perfectamente la posibilidad de que los bienes gananciales se inscriban en el Registro de la Propiedad a nombre de uno solo de los cónyuges, cuando el adquirente no expresa que adquiere para su sociedad de gananciales, si bien, en tal caso, el bien se inscribirá a pesar de todo con carácter «presuntivamente ganancial» (ex art. 94.1 RH), una advertencia que hubiese bastado por sí sola para poner en tela de juicio la legitimación de la única titular registral para disponer unilateralmente del bien inscrito. Por su parte, el art. 93.1.I RH sienta la regla general de inscripción a nombre de marido y mujer de los bienes inmuebles gananciales adquiridos por ambos conjuntamente y a título oneroso, que es lo que hubiese procedido en el caso que venimos analizando aquí. El problema quizá se originó porque la escritura pública de adquisición del piso litigioso se otorgó cuando la sociedad de gananciales llevaba ya años extinta y sin reparar en que la fecha de la adquisición de la propiedad debía retrotraerse a la de celebración del propio negocio jurídico de adquisición, es decir, a 1955.

24 Si en el Registro hubiese constado el carácter ganancial del inmueble (ya fuese por la vía del art. 93, ya por la del $94 \mathrm{RH}$ ), la limitación del poder de disposición de la madre de los litigantes habría sido una consecuencia necesaria y perceptible, ya que, advertido el carácter común del inmueble, no se habría podido sortear la aplicación de las 
Lógicamente, la misma inexactitud contenida en la escritura es la que reproduce el asiento registral que pregona la titularidad de la madre (ex art. 9 $\mathrm{LH}$, letras c] y e] $)^{25}$, razón por la cual dicha inscripción era nula, de acuerdo con el art. 31 LH. Sin embargo, nada de ello se había puesto aún de manifiesto cuando en 2007 la titular registral cede la nuda propiedad del inmueble inscrito a su favor a sus hijas, a cambio de una prestación de alimentos. Ellas nada tuvieron que ver en el negocio jurídico del que resultó la inexactitud del Registro, ni en sus vicisitudes ulteriores, por lo que, obviamente, se las debe considerar terceras respecto de uno y otras. Y por esa misma razón merecían, en principio - sin perjuicio de que, lógicamente, hubieran de concurrir las demás circunstancias que para ello exige el art. $34 \mathrm{LH}-$, que su confianza en la información publicada por el Registro fuese atendida.

\section{LA IMPUGNACIÓN DE LA VALIDEZ DEL NEGOCIO JURÍDICO BASE DE LA TRANSMISIÓN DE DERECHOS A LAS ADQUIRENTES DEMANDADAS}

\subsection{La irrelevancia de la naturaleza jurídica propia del contrato celebrado a los efectos de determinar su validez en el caso de autos}

Como se desprende del título de este trabajo y de las alusiones que en las páginas previas hemos efectuado al mismo, el negocio jurídico que celebraron la madre del actor y sus hermanas merece calificarse rectamente como contrato de alimentos, sometido a las disposiciones contenidas en los arts. 1791 a $1797 \mathrm{CC}^{26}$. Sin embargo, hay que precisar que la naturaleza jurídica propia de este contrato no tuvo incidencia alguna en el debate jurisdiccional relativo a la validez del negocio que da base a la aplicación del art. $34 \mathrm{LH}$ : el actor no intentó en ningún momento combatir la validez del contrato de

normas que rigen los actos de disposición de los bienes gananciales, concretamente, los arts. 1322 y 1375 a 1391 CC para cuando aún está constante la sociedad, y las más generales que rigen la disposición de bienes comunes de la sociedad posganancial o hereditaria, ex arts. 1410 CC en relación con los arts. 397 y 399 CC.

25 A tenor del art. 9 LH, en la inscripción deberá hacerse constar: «c) La naturaleza, extensión y condiciones, suspensivas o resolutorias, si las hubiere, del derecho que se inscriba, y su valor cuando constare en el título», así como «e) la persona natural o jurídica a cuyo favor se haga la inscripción [...]", datos que, lógicamente, han de proceder del documento público que se presenta para que se practique la correspondiente inscripción.

26 En el apartado siguiente, al que nos remitimos, abordaremos la cuestión de la naturaleza y caracteres del contrato de alimentos como título apto para la transmisión de la propiedad y otros derechos reales de carácter oneroso. 
alimentos sobre la base de los elementos que lo configuran, o de los rasgos que lo caracterizan como tal, o de la finalidad que presidió su celebración, lo que podía haberle llevado, por ejemplo, a plantear la existencia de algún vicio de la voluntad de la madre alimentista en el caso concreto $^{27}$, o a poner en tela de juicio la aleatoriedad del negocio celebrado ${ }^{28} \mathrm{o}$, fundamentalmente, a combatir la licitud de su causa, tratando de demostrar la existencia de una simulación de contrato encaminada a eludir la aplicación de las normas sucesorias en materia de legítimas, aspecto en el cual tiene también su importancia que el negocio celebrado fuese oneroso o gratuito. Pero nada de esto hay en las argumentaciones del demandante ${ }^{29} \mathrm{y}$, por consiguiente, los órganos judiciales que conocieron del caso tampoco se pronuncian con carácter decisorio al respecto ${ }^{30}$.

27 Que existan vicios del consentimiento de las partes contratantes es una posibilidad que cabe contemplar y que, de acreditarse, produciría la anulabilidad del contrato por causa de error o dolo-vicio. Un caso concreto y reciente en el que incluso se analizan las disposiciones de dinero hechas desde la cuenta de la alimentista puede verse en la SAP de Huelva de 20 de noviembre de 2018 (JUR 29794).

28 En este sentido, la SAP de Sevilla de 25 de febrero de 2016 (AC 2016, 1088) considera que la aleatoriedad es elemento esencial del contrato de alimentos, de modo que la certeza de la inminencia de la muerte del alimentista determina su nulidad.

29 Como se indica con carácter de obiter dictum en el FJ 3 de la STS de 29 de noviembre de 2018, tampoco discutió el demandante el cumplimiento de las prestaciones del contrato de alimentos por las cesionarias demandadas, lo que, a decir del Tribunal, «hubiera podido hacer valer mediante el ejercicio de la acción resolutoria prevista en el propio contrato para tal eventualidad», algo que asume también sin discusión Vela Sánchez (2019: 8-9). No compartimos en absoluto esta conclusión que, por otra parte, presupondría, lógicamente, la asunción de la validez del propio contrato. El actor no es parte en el contrato de alimentos, por lo que carecería de legitimación para ejercitar la acción de resolución del mismo por incumplimiento del alimentante prevista en el art. 1795 CC. Por otra parte, no se comprende cómo podría ejercitarse dicha acción, en su caso, siete años después de haberse extinguido el contrato por muerte de la cedente alimentista.

30 Sin embargo, el detalle no pasa inadvertido para la Excma. Sra. ponente, que introduce una referencia a esta cuestión en la propia STS de 29 de noviembre de 2018 (RJ 5395), al perfilar y aclarar la naturaleza de la acción de impugnación ejercitada y advierte: «vi) Hay que partir de que, en el caso, el conflicto entre las partes no se suscita en su condición de herederas, pues la acción ejercitada no es la de impugnación del contrato celebrado entre la madre y las hermanas del demandante haciendo valer una simulación que encubriera una donación» (FJ 3, punto 3). La precisión adquiere sentido porque, aunque esa acción no se ejercitara en el caso de autos, es un planteamiento habitual cuando se celebra un contrato de alimentos entre miembros de una 
Quiere con ello decirse que, a efectos del debate sobre la validez del negocio jurídico celebrado entre la madre otorgante y las hermanas demandadas, careció de toda influencia que se tratara de un contrato de alimentos; el planteamiento del actor — centrado, como enseguida veremos, en la nulidad del acto dispositivo realizado por su madre en cuanto que mera copropietaria del piso litigioso- habría podido ser exactamente el mismo si se hubiera celebrado entre ellas una compraventa, una permuta o un contrato de renta vitalicia. La discusión en torno a la gratuidad u onerosidad del contrato de alimentos, como rasgo propio y característico del mismo - que sí aflora en el debate jurisdiccional- se considera relevante para determinar si concurre o no otro de los requisitos del art. $34 \mathrm{LH}$, pero no se explora a los efectos de establecer si, efectivamente, las demandadas celebraron con su madre un verdadero contrato de alimentos o, en realidad, se trató de encubrir con él un negocio lucrativo.

\subsection{La vía de impugnación elegida por el actor: atacar la validez del negocio por constituir un acto de disposición de la cosa común realizado individualmente $y$ en nombre propio por uno solo de los partícipes. Planteamiento del problema}

Como acaba de indicarse, la concreta naturaleza jurídica del contrato de alimentos fue, en sí misma, irrelevante para fundamentar las pretensiones del demandante en punto a la invalidez del negocio en cuya virtud sus hermanas pretendían haber adquirido la propiedad del piso que otrora fuera vivienda de la familia. Su asistencia letrada escogió una vía distinta y más general de impugnación de aquel contrato en cuanto que, por las circunstancias concretas concurrentes en el caso, la madre disponente no resultaba ser propietaria plena y exclusiva del inmueble cedido, sino tan solo una partícipe más en las diversas comunidades que se habían constituido sobre el bien en cuestión y, en consecuencia, carecía de legitimidad para disponer por entero del mismo sin contar con el consentimiento o la representación del resto de los comuneros.

Partiendo del carácter ganancial asignado al piso litigioso, calificación que el Tribunal Supremo mantiene al rechazar el recurso extraordinario por infracción procesal interpuesto por las demandadas, se deduce que la madre cedente nunca fue propietaria en exclusiva del mismo, sino cotitular del dominio que, originariamente, se adquirió para la sociedad de gananciales que tenía con su marido mientras este estuvo vivo; con posterioridad, la muerte

misma familia que da finalmente al traste con las expectativas sucesorias de algún otro de sus integrantes. 
del esposo produjo, por imperio de la ley, la transmutación de aquella sociedad dinámica en la estática comunidad posganancial, y, paralelamente, la constitución de la comunidad hereditaria integrada por todos los sucesores del difunto, recayendo ambas sobre el piso litigioso.

$\mathrm{Y}$ es que es sabido que la muerte de uno de los cónyuges provoca como consecuencia ineludible la disolución de pleno derecho de la comunidad de gananciales que viniera rigiendo su matrimonio (ex arts. $1392.1 .^{\circ}$ y 85 CC), una comunidad que, desde ese momento y hasta su liquidación y partición, se transmuta en la denominada comunidad posganancial. Paralelamente, el deceso de ese mismo esposo comporta también la apertura de su sucesión (ex art. $657 \mathrm{CC}$ ), y, con ella, si el difunto tuviere más de un sucesor, la constitución de la comunidad hereditaria, tras un período más o menos prolongado de herencia yacente. La confluencia de ambos fenómenos propicia que, con frecuencia, unos mismos bienes, los gananciales, formen parte de dos comunidades indivisas de tipo germánico ${ }^{31}$, pendientes de liquidación y partición: la comunidad posganancial y la comunidad hereditaria ${ }^{32}$. El supuesto más habitual y paradigmático es el de la persona casada que fallece dejando a su cónyuge viudo y huérfanos de padre o madre a los hijos de ambos como, precisamente, sucedió en el caso de autos ${ }^{33}$.

En esta situación, la titularidad de los bienes integrados en ambas masas — la posganancial y la hereditaria - es difusa, en el sentido de que correspon-

31 En contra, la STS de 15 noviembre 2012 (RJ 2013,14), en un pronunciamiento de cierto interés en el caso pero con carácter de obiter dictum, afirma que la posganancial es una comunidad de tipo romano u ordinario. Véase su FJ 2.

32 Así se explica la situación en la STS de 17 de enero de 2018 (RJ 2018, 36) a la que se remite la que sirve de base a estas páginas: «Son partícipes de la comunidad postganancial el viudo y los herederos del premuerto. El viudo es, en primer lugar, cotitular del patrimonio postganancial indiviso. Pero, además, al viudo le corresponde la cuota usufructuaria en la herencia del premuerto, en la que está incluida la cotitularidad que a este último le correspondía en el patrimonio ganancial». Y más adelante: «Mientras no se proceda a la partición del caudal hereditario, integran la comunidad tanto los bienes privativos del premuerto como, hasta que se liquide la sociedad de gananciales y se adjudiquen bienes concretos, la participación del premuerto en el patrimonio ganancial».

33 Aunque caben, por supuesto, muchas otras combinaciones, como, por ejemplo, que al cónyuge difunto sin hijos propios le sucedan el supérstite y uno o varios ascendientes (ex arts. 807.2. ${ }^{\circ}$ y 809 CC), o que fallezcan simultáneamente ambos esposos (por ejemplo, en un accidente), dejando cada uno de ellos sus propios sucesores no comunes (como sucedería, por ejemplo, en el caso de que el matrimonio casado en gananciales lo haya sido en segundas nupcias, aportando cada cual hijos propios). 
de a una comunidad indivisa sobre la integridad del patrimonio que no permite la distinción de cuotas, ni en la propia comunidad, ni en cada uno de los bienes que la conforman, de suerte que si, por cualquier razón, se desea o se necesita disponer de alguno de ellos en particular, antes de proceder a las sucesivas liquidaciones y particiones de la comunidad posganancial y de la hereditaria $^{34}$, deberá necesariamente concurrir el consentimiento unánime de todos y cada uno de los partícipes (art. ex art. 1410 en relación con los arts. 397 y 399 CC) ${ }^{35}$. Pero esta exigencia no siempre se cumple, como precisamente sucede en el caso que venimos considerando, en el que nos encontramos con un acto dispositivo realizado por el cónyuge supérstite - la madre de los litigantes - sobre un bien de la comunidad posganancial y hereditaria ${ }^{36} \sin$ contar con el consentimiento del resto de sucesores del cónyuge premuerto ${ }^{37}$.

34 En puridad, la partición y liquidación de la comunidad posganancial han de preceder a las de la comunidad hereditaria, pues es preciso determinar lo que se atribuye de aquella al cónyuge premuerto, para determinar el as hereditario sobre el que se constituye propiamente la comunidad de los sucesores del difunto.

La regla se predica igualmente respecto de la disposición de bienes en comunidad ordinaria; la diferencia en tal caso es que la existencia y determinación de las cuotas que caracteriza a ese tipo de organización de la situación de cotitularidad permite la disposición individual de su derecho por parte de cada comunero (ex art. 399 CC), a diferencia de lo que sucede en las comunidades de tipo germánico o en mano común, a que se adscriben tanto la comunidad posganancial como la hereditaria. La regla general de la necesidad del consentimiento de todos los condóminos para disponer del bien común es, obviamente, igualmente aplicable cuando tan solo hay que liquidar y partir la una o la otra.

36 Aunque no hay certeza sobre ello, ya que del relato fáctico tanto de la sentencia de apelación como de la de casación no pueden extraerse conclusiones claras al respecto, es muy posible que la vivienda litigiosa fuera el único bien ganancial del matrimonio, excepción hecha del ajuar doméstico, y que tampoco el padre hubiera dejado al fallecer un importante patrimonio privativo. Si la realidad fuera como la hemos conjeturado, la expectativa de la comunidad hereditaria de los sucesores del padre premuerto se referiría a la mitad del inmueble litigioso, que es la cuota que se atribuiría a los herederos del difunto de haberse practicado la previa y preceptiva liquidación de la sociedad de gananciales, una cuota sobre la que los hijos ostentarían una titularidad gravada por el usufructo vidual correspondiente a su madre (ex arts. 1404, 808 y 834 CC). Esta, por su parte, resultaría adjudicataria en plena propiedad de la otra mitad de la vivienda a consecuencia de la misma liquidación de la sociedad de gananciales.

37 Cosa similar sucedió en el caso enjuiciado por la STS de 7 de junio de 2018 (RJ 2394), en el que el padre de los litigantes vendió a una de sus hijas un bien de la comunidad posganancial no liquidada y originada por el fallecimiento de su esposa. A partir de ahí el caso varía, porque lo que la hija adquirente pretendía era el saneamien- 
Llegados a este punto, se impone aclarar qué calificación jurídica merecen los actos o contratos en los que un partícipe, sin advertir a su contraparte de la situación de cotitularidad ${ }^{38}$, dispone por entero y en su propio nombre de la cosa común, prescindiendo del consentimiento de los demás comuneros y sin ostentar ${ }^{39}$ ni $\operatorname{arrogarse}^{40}$ su representación voluntaria. En la respuesta que

to por evicción a costa de sus hermanos, dado que ese mismo bien se le adjudicó en la partición de la herencia. Sobre la sentencia, véase el comentario de Toral Lara (2019: 6), que califica el supuesto como un caso de venta parcialmente ajena.

No se plantea problema alguno si el comunero disponente hace saber a su contraparte que es solo un cotitular más de los derechos sobre el bien, como sucedió en el caso enjuiciado por la STS de 3 de febrero de 2009 (RJ 266), supuesto sobre el que no puede plantearse duda alguna sobre su validez. Véanse los FF. JJ. 2 y 3 . Hay que advertir, no obstante, que cabe la posibilidad de que el propio disponente ignore la existencia de esa situación de comunidad, como, probablemente, sucedió en el caso enjuiciado por la sentencia que aquí nos trae.

39 Obviamente, si el partícipe disponente es representante voluntario de los demás, no hay caso, como tampoco lo habrá si es un representante legal que obtiene la preceptiva autorización judicial para disponer del bien en nombre de su hijo o tutelado, ex arts. 166 y $271.2 .^{\circ}$ CC. Si no dispusiera de ella, el contrato se consideraría nulo, como sucedió en el caso enjuiciado por la STS 22 de abril 2010 (RJ 2010, 2380) del Pleno de la Sala 1.a , que declaró nula o inexistente la venta de la casa familiar posganancial realizada por el padre viudo en su propio nombre y como representante legal de sus hijos menores de edad, por no contar con la preceptiva autorización judicial.

El matiz es importante, porque cuando un comunero se presenta sin serlo como representante voluntario del resto, se considera, mayoritariamente y casi sin fisuras, que el caso entra en la órbita del art. 1259 CC, que declara "nulo» el contrato celebrado por el falsus procurator, debido a que no ha concurrido en modo alguno el consentimiento del falsamente representado, que es, sin embargo, por su invocación, parte en el contrato. En este sentido se pronuncian, entre otros, López Frías (2013: 15-16), Pérez Gurrea (2012: 3569) e Yzquierdo Tolsada (2016: 132, 134). Los casos enjuiciados por las SSTS de 13 de noviembre de 2001 (RJ 9689) y 9 de octubre de 2008 (RJ 5684) responden a este supuesto de hecho, si bien en ninguna de ellas se hace aplicación específica del precepto, al confirmarse la decisión de los órganos de instancia de que la venta efectuada sin el consentimiento de todos los comuneros es radicalmente nula. En el FJ 2 de la última sentencia citada se puede leer lo siguiente: «Se plantea el tema de la nulidad del negocio jurídico celebrado en representación sin poder, aunque no se vislumbra el efecto que pueda tener en el presente caso, ya que el artículo 1259 del Código civil prevé la ratificación. El negocio jurídico precisa como elementos esenciales el consentimiento, objeto y causa, conforme al artículo 1261 del Código civil; en la representación sin poder, falta el elemento del consentimiento porque el falso representante no emite su declaración de voluntad sino que lo hace en nombre de otro, y este, el seudorepresentado tampoco la 
corresponda a esta cuestión, de la que dependerán obviamente las consecuencias jurídicas que deban seguirse del supuesto, no influye de modo determinante que la situación de cotitularidad que se contemple sea una comunidad de tipo romano o germánico, pues, como veremos, tanto la doctrina como la jurisprudencia vienen dispensándoles un tratamiento similar en este punto ${ }^{41}$; ello no obstante, dado que en el caso que aquí nos trae nos movemos siempre

emite porque nunca dio poder de representación: es, pues, un negocio jurídico inexistente, terminología o incluso concepto que se confunde con nulidad y también se identifica una y otra o se incluye la primera en la segunda; así, cuando se da la ratificación, se completa con el consentimiento aquel negocio jurídico que, de inexistente (o nulo) pasa a ser existente, válido y eficaz». Por su parte, la STS 15 de enero de 2013 (RJ 2276) enjuicia un caso de extralimitación de la mandataria respecto del poder de sus hijos que tenía atribuido, por lo que procede igual solución y, de nuevo, aunque confirma la nulidad de las ventas celebradas, no se encuentra referencia alguna al art. 1259 CC.

No obstante, la naturaleza de la comunidad sí que influye en una cuestión derivada de la anterior y que tan solo cabe plantear en puridad, en nuestra opinión, cuando la situación de cotitularidad sobre el bien de que dispone el partícipe es de comunidad romana u ordinaria: se trata de si es posible mantener la eficacia de la disposición de la cuota que corresponda al comunero disponente. En las comunidades de tipo germánico, como lo son la posganancial y la hereditaria, esta cuestión no puede plantearse, debido a la inexistencia, por definición, de cuotas propiamente dichas, salvo que la herencia esté constituida por un único bien. Al respecto, la STS de 9 de octubre de 2008 (RJ 5684) se refiere a la imposibilidad de otorgar eficacia a la venta de la cuota del partícipe enajenante como consecuencia de ese mismo contrato, a pesar de existir en el caso una comunidad ordinaria de bienes: «La venta, como negocio jurídico de disposición o alteración jurídica, de una cosa común, está prohibida por el artículo 397 del Código civil y no cabe incardinarla en el supuesto de venta de cosa ajena, sino que se hace como propia y en perjuicio directo de los copropietarios, con sanción de nulidad absoluta como han afirmado sentencias de esta Sala, como la de 26 de febrero de 1982 (RJ 1982, 790) y la de 13 de noviembre de 2001 ( RJ 2001, 9689) que cita otras muchas anteriores. Esto, como primer apartado, se relaciona con el segundo, que defiende la validez de la venta de la cuota parte del vendedor de la que sí era propietario: lo que no es aceptable porque vendió la cosa como un todo, sin poder ahora dividirse y las dos sentencias citadas afirman también la imposibilidad de subsistencia de la validez parcial del contrato" (FJ 2). Hay que precisar, con todo, que la solución es acorde con el hecho de que todo el negocio se considerara nulo por el Alto Tribunal. Por el contrario, en el caso enjuiciado por la STS de 15 de enero de 2013 (RJ 2276) sí se otorga validez a la venta de las cuotas de los partícipes válidamente vendidas de acuerdo con el poder que ostentaba la madre mandataria a pesar de que se decretaran nulas las ventas de las cuotas de los comuneros no representados en virtud de dicho poder, en cuyo uso la disponente se extralimitó. 
en el ámbito del segundo supuesto, el discurso se construirá esencialmente sobre esa base.

Siendo, pues, la cuestión fundamental dilucidar qué calificación jurídica corresponde a estos actos y, en función de ella, si es posible mantener o no su validez como negocio jurídico apto para la aplicación del art. $34 \mathrm{LH}$, hay que partir de las siguientes ideas:

1. ${ }^{a}$ La jurisprudencia y, en menor medida, también la doctrina científica han mantenido posiciones diversas respecto a la cuestión en liza, pudiendo identificarse, fundamentalmente, dos opciones claramente contrapuestas al respecto ${ }^{42}$ : una que sostiene la nulidad, con base en varios argumentos distintos, de los actos de disposición de la cosa o derecho común sin que concurra el consentimiento de todos los partícipes, y otra, de signo opuesto, que mantiene su validez, por considerar que el caso debe incardinarse en el más amplio supuesto de la venta de cosa (parcialmente) ajena. Ambas líneas se explorarán con mayor detalle en los epígrafes subsiguientes.

2. ${ }^{\text {a }}$ Entendemos que hay dos razones fundamentales que posibilitan la convivencia de interpretaciones tan diversas.

a) En primer lugar, la falta de concreción del fundamento de la misma exigencia de que concurra el consentimiento de todos los comuneros a la hora de disponer del bien o derecho común, sea cual sea la naturaleza de la comunidad. Hay quien lo sitúa en el art. 397 CC, entendiendo el término «alteraciones» en un sentido amplio que incluye las de tipo jurídico ${ }^{43}$; otros lo radican en el art. $399 \mathrm{CC}^{44}$; también se invoca el art. $597 \mathrm{CC}$ arguyendo que debiera estar más en sede de comunidad que en sede de servidumbres ${ }^{45}$, y, finalmente, tampoco faltan opiniones que consideran que la regla es una exigencia de los principios básicos que rigen nuestro sistema transmisivo, dado que nadie puede transmitir lo que no tiene $e^{46}$.

b) Y, a partir de lo anterior, el hecho de que no existe norma jurídica alguna que establezca expresamente y con precisión la sanción aplicable, ni a un supuesto, ni al otro: ningún precepto legal precisa qué calificación corresponde a los actos realizados en solitario por el comunero disponente, prescindiendo de la voluntad del resto de los cotitulares del bien o derecho común;

42 Lo que ha valido para que la doctrina científica califique la posición del Tribunal Supremo en este asunto como "en absoluto clara» (López Frías, 2013: 4), «extraordinariamente vacilante» (Pertíñez Vílchez, 2012: 3) o «variable e insegura» (Estruch Estruch, 2016: 1234).

43 En esta línea, se inscribe la STS 9 de octubre de 2008 (RJ 2008, 5684).

44 Como Estruch Estruch (2016: 1244-1245) y Fernández Chacón (2018: 178).

45 Véase al respecto López Frías (2013: 2).

46 En este último sentido, véase López Frías (2013: 1). 
y tampoco hay norma legal, no ya que disponga la calificación oportuna para la venta de cosa ajena, sino que tan siquiera contemple con carácter general la figura $^{47}$. Son estas carencias las que han tratado de solventar autores y tribunales por la vía de la hermenéutica jurídica.

Planteado el problema y esbozadas las posibles vías de solución del mismo, corresponde ahora profundizar en las dos opciones que se proponen para resolverlo, dado que la primera de ellas es la que invoca el demandante y la otra es la que finalmente acoge el Tribunal Supremo en la Sentencia de 29 de noviembre de 2018 que inspira estas líneas.

\subsection{La pretensión esgrimida por el actor: el acto de disposición del bien de la comunidad posganancial realizado en solitario y en su propio nombre por la viuda es nulo de pleno derecho}

La declaración de nulidad de pleno derecho de los actos de disposición de la cosa común realizados en solitario y en su propio derecho por un partícipe se ha producido sobre la base de la carencia de alguno de los elementos esenciales del contrato (ex art. $1261 \mathrm{CC}$ ). Así, se han apreciado, concretamente, las siguientes circunstancias invalidantes del negocio:

a) La inexistencia del consentimiento unánime e imprescindible de todos los comuneros, impuesta por el art. 397 CC, para efectuar alteraciones en la cosa común, término que se considera comprensivo no solo de las modificaciones físicas, sino también de las jurídicas, entre las que se encuentran los actos de disposición ${ }^{48}$. La contravención de este precepto, dado su carácter de norma imperativa o prohibitiva específicamente aplicable al caso, traería de suyo la aplicación de la sanción de nulidad del art. 6.3 CC, al no establecerse expresamente una sanción distinta para el caso de contravención. De acuerdo con este planteamiento, concluye la STS de 7 de marzo de 2012 (RJ 4059):

47 Sí contempla el Código Civil el legado de cosa ajena, en los arts. 861 y 862, que disponen su validez si el testador conocía la ajenidad de la cosa en el momento de ordenar el legado y su nulidad en caso contrario.

48 Refutando que el art. 397 CC pueda interpretarse de este modo, con argumentos de interpretación histórica, literal y sistemática, véase Estruch Estruch (2016: 12391245). Además, el autor (2016: 1245-1248) considera que, aun cuando dicho artículo fuera el aplicable al caso que nos ocupa, no debiera aplicarse automáticamente la sanción de nulidad del art. 6.3 CC —en contra de lo que indica este precepto, que la establece como sanción general para el caso de que no se haya establecido específicamente otra distinta para el caso de contravención de la norma imperativa o prohibitiva-, dado que ello provoca, en su opinión, resultados contraproducentes para todos los interesados. 
[...] el vendedor no gozaba de la libre disponibilidad del bien transmitido, carente el acuerdo del consentimiento necesario para ser catalogado de contrato (art. 1261 CC), pues no bastaba con el asentimiento del enajenante sino que se precisaba el de los demás condóminos (art. $397 \mathrm{CC}$ ), por lo que no se le pueden reconocer efectos obligacionales al acuerdo analizado, en cuanto nulo (FJ 2$)^{49}$.

b) La falta de objeto del contrato celebrado por el partícipe, al razonar que «sin confundir objeto con poder de disposición sobre el objeto, el de la compraventa está integrado no sólo por la cosa vendida, sino también por los derechos que radicando sobre la misma son materia de la transmisión que se pretenda operar ${ }^{50}$, lo que supone, en definitiva, integrar el poder de disposición del tradens en el título ${ }^{51}$ y no en el modo que ha de unirse al contrato para surtir efectos jurídico-reales.

49 En el mismo FJ 2 de la sentencia citada en el texto se invoca en apoyo de la solución acogida una línea jurisprudencial anterior consolidada: «[...] la solución generalmente adoptada por esta Sala en sus sentencias de las últimas décadas coincide con la de la sentencia de primera instancia de este litigio, es decir nulidad de la compraventa por aplicación combinada de los arts. 397 y 1261 CC al implicar la disposición de la cosa común por uno solo de los partícipes una alteración que requeriría el consentimiento de los demás. Es el criterio seguido por las SSTS 19-12-1985, 8-7-1988, 25-5-1990, 23-10-1990, 30-6-1993, 24-7-1998 y 13-11-2001, así como también por la STS 9-10-2008, ya citada, en otro de sus fundamentos».

50 Es el mismo argumento en el que se ha basado la línea jurisprudencial que durante un tiempo ha considerado nula la venta de cosa ajena en el ámbito de la venta múltiple del art. 1473 CC: las sentencias del Tribunal Supremo de 10 de junio de 2003 (RJ 4598), 16 de junio de 2003 (4243) y 25 de mayo de 2006 (RJ 2006, 3340). Véanse al respecto Fernández de Villavicencio Álvarez-Ossorio (1994: 214), que afirma que «la ajenidad, se conozca o no, no convierte a la cosa en objeto inhábil para la perfección de la compraventa; la cosa existe y sirve, aun siendo ajena, como objeto del contrato", Cuena Casas (1996: 1446-1447) y Murga Fernández (2011: 2). Contundentemente, contradice el argumento la STS de 5 de mayo de 2008 (RJ 5502), confirmatoria de la anterior de 2007, en la cual de manera aún más tajante se indica: «La venta de cosa ajena es válida, en ningún caso se puede tildar de inexistente por falta de objeto; el objeto existe, es el piso; distinto es la falta de poder disposición sobre el objeto, que da lugar a la ineficacia y puede dar lugar a la adquisición a non domino en virtud del art.464 CC en los bienes muebles y del art. $34 \mathrm{LH}$ para los bienes inmuebles».

51 Estruch Estruch (2016: 1250) critica esta jurisprudencia al considerar que introduce, ya sea en el objeto del contrato, ya sea en su causa, el poder de disposición del transmitente como elemento esencial del mismo, a los efectos del art. 1261 CC. Casi toda la doctrina actual se muestra contraria a admitir este planteamiento. En tal sentido, véase Murga Fernández (2011: 4-5). 
c) La inexistencia o los vicios de la causa, al entenderse - aunque con mucha menor frecuencia que los argumentos anteriores - que la falta de poder de disposición del partícipe contratante aqueja a este elemento esencial del contrato, por «no coincidir la titularidad parcial que ostenta el enajenante con la plena gama de titularidades de derechos que ostenta residualmente el copartícipe».

Sea cual sea el elemento estructural del que se considere que carece el contrato, lo cierto es que la asunción de su nulidad impedirá la consolidación del dominio del adquirente sobre la base del art. $34 \mathrm{LH}$, ya que, como hemos explicado con anterioridad, la inscripción de su derecho, aun cumpliendo el resto de requisitos que este precepto le impone, no impediría la aplicación del art. $33 \mathrm{LH}$, que exige que el negocio celebrado con el titular registral sea válido, una condición que no reúnen obviamente los contratos radicalmente nulos. En consecuencia, y partiendo de esta calificación, quien contratase con el titular registral a título oneroso e ignorando que es solo un partícipe más podrá consolidar su adquisición tan solo a través de la usucapión extraordinaria, porque carecería igualmente del título válido que exige la ordinaria (arg. ex arts. 1940, 1953 y 1959 CC), pero en ningún caso a través del mecanismo previsto en el art. $34 \mathrm{LH}^{52}$.

Por lo que respecta al predicamento que ha obtenido la nulidad de la disposición por entero del bien común sin la participación de todos los comuneros, la jurisprudencia se ha decantado por esta calificación reiteradamente, tanto en supuestos de disposición por un solo cónyuge de bienes de la comunidad posganancial ${ }^{53}$ como en casos de disposición de bienes de la comunidad hereditaria sin el consentimiento de todos sus partícipes ${ }^{54}$, como también al tratarse de disposición por un partícipe de la comunidad ordinaria ${ }^{55}$. En

52 En este mismo sentido, véanse Estruch Estruch (2016: 1252) y Fernández Chacón (2018: 172-173).

53 Véanse en este sentido las SSTS de 14 de febrero (RJ 676), 14 de marzo (RJ 1203) y 5 de junio (RJ 3587) de 2000; 19 de junio de 2002 (RJ 5225); 23 de enero de 2003 (RJ 607); 27 de febrero (RJ 1768), y 9 de mayo de 2007 (RJ 3439).

54 Véanse las SSTS de 13 de noviembre de 2001 (RJ 9689) y 7 de marzo de 2012 (RJ 4059), FJ 2. Sobre esta sentencia, véase el comentario de Pertínez Vílchez (2012: passim). Por su parte, la STS de 23 de marzo de 2012 (RJ 5573) parece también adscribirse a esta misma línea, si bien en el caso de autos se consideró que la venta debía surtir efectos obligacionales, sin que procediera su nulidad, porque se consideró que las partes conocían suficientemente el objeto de la venta, la cuota participativa y que ello no vinculaba al resto de los partícipes, que también enajenaron sus propios derechos. Además, se trataba del único bien relicto de la herencia. Véase su FJ 8.

55 Véanse la STS de 9 de octubre de 2008 (RJ 5684) y la STS de 26 de marzo de 2012 (RJ 5576), en cuyo FJ 12 se resumen las distintas líneas jurisprudenciales al respecto, 
cambio, no puede decirse que esta opción encuentre el apoyo de un amplio número de autores ${ }^{56}$.

\subsection{La decisión del Tribunal Supremo: el acto de disposición del bien de la comunidad posganancial realizado en solitario y en su propio nombre por la viuda es válido, al constituir un supuesto de venta de cosa (parcialmente) ajena}

Abandonando la línea anterior, la STS de 29 de noviembre de 2018 considera que el caso de autos debe incardinarse en el ámbito de la venta de cosa ajena ${ }^{57}$, cuya naturaleza comparte, al disponer el comunero de algo en lo que tiene derecho o de lo que es copropietario, si bien solo en parte ${ }^{58}$. Se trata, en definitiva, de aplicar al negocio jurídico de disposición celebrado unilateralmente por el partícipe la misma doctrina elaborada para la venta de cosa ajena, de acuerdo con la cual este negocio debe reputarse válido en nuestro ordenamiento jurídico, si bien sus efectos son meramente obligacionales y no reales: dado que no existe una obligación del vendedor de transmitir la propiedad,

dándose por imperante y mayoritaria la que decreta la nulidad de la venta por falta de los consentimientos necesarios del resto de los partícipes.

Sin entrar en la discusión sobre los argumentos legales que esgrime la jurisprudencia, concluye Herbosa Martínez (2013: 4) que la venta de todo el bien común por uno solo de los partícipes es nula de pleno derecho por carecer de estos elementos esenciales.

57 Para Ragel Sánchez (2012: 45; 2013: 871): «Venta de cosa ajena es la que realiza una persona sobre una cosa que no le pertenece en todo o en parte y sin tener representación de su dueño para disponer de ella. En otras palabras: es una venta en la que el vendedor carece del poder de disposición sobre la cosa». En sentido similar, Fernández Chacón (2018: 77). Puntualiza Herbosa Martínez (2013: 1) que si bien la venta de cosa ajena no está regulada en el Código Civil, existe cierto consenso doctrinal a la hora de apreciar tal situación cuando el vendedor, al perfeccionarse la venta, no es dueño del bien objeto del contrato.

Pérez Gurrea (2012: 3562) considera que los supuestos de venta de bienes hereditarios por un coheredero antes de la partición, de venta de bienes gananciales por el viudo antes de la liquidación de la sociedad y de venta del bien en común por un condómino constituyen supuestos de venta de cosa parcialmente ajena en los que concurren las mismas razones para su validez que en la venta de cosa ajena. También lo consideran Goñi Rodríguez de Almeida (2005: 647), Pertínez Vílchez (2012: 5), Estruch Estruch (2016: 1252, 1254) e Yzquierdo Tolsada (2016: 133). Con mayor indefinición, sostiene Fernández Chacón (2018: 188) que en los casos de disposición del bien común de la comunidad hereditaria por uno de los coherederos el supuesto de hecho es un tertium genus entre la venta de cosa propia y la de cosa ajena. 
el poder de disposición del tradens no se considera como un requisito esencial del título - por consiguiente, su falta no lo invalida y el negocio conserva su eficacia obligacional ${ }^{59}$ - , sino de la tradición del bien como modo de adquirir (ex art. $609 \mathrm{CC})^{60}$. Esta interpretación se sustenta, aparte de en esta idea capital, en argumentos históricos, en la propia existencia de la obligación de saneamiento por evicción, que carecería de sentido si la venta de cosa ajena fuese nula, y en el funcionamiento de la usucapión como modo de adquirir la propiedad y demás derechos reales ${ }^{61}$.

Salvada de este modo la validez del acto dispositivo realizado en solitario por el comunero titular registral, existe vía libre para la aplicación del art. $34 \mathrm{LH}$ si concurren el resto de sus requisitos, puesto que no puede oponerse a la adquisición del tercero la norma contenida en el art. 33 LH. Es más, se considera que aquel precepto está, precisamente, para salvaguardar a los terceros de la carencia de poder de disposición de su transmitente ${ }^{62}$, pues, de otro modo, se privaría de toda eficacia o sentido a la norma ${ }^{63}$. La validez del título

59 Como señala López Frías (2013: 2): «Precisamente la necesaria diferenciación entre estos dos aspectos (obligacional y real) que componen el mecanismo de transferencia del dominio, constituye la base sobre la que se afirma en la doctrina la validez de la venta de cosa totalmente ajena, y a fortiori la de la venta de una cosa que solo en parte es propia». En sentido similar, véase Pérez Gurrea (2012: 3569).

60 Esta es la interpretación imperante hoy en la doctrina mayoritaria y en la jurisprudencia. Véanse al respecto, entre otros, Cuena Casas (1996: 1446-1447), Goñi Rodríguez de Almeida (2005: 644), Murga Fernández (2011:5-7), Pérez Gurrea (2012: 35693570) y Estruch Estruch (2016: 1248 y 1253-1257).

61 Sobre estas cuestiones, véase Fernández de Villavicencio Álvarez-Ossorio (1994: 175) y Cuena Casas (2008: passim).

62 Una idea que se reitera en las SSTS de 21 de junio de 2000 (RJ 5736), 22 de diciembre de 2000 (RJ 10136), 22 de junio de 2001 (RJ 5071), 6 de mayo de 2004 (RJ 3569), 24 de junio de 2004 (RJ 3637), 25 de octubre de 2004 (RJ 7033) y 30 de diciembre de 2005 (RJ 2006, 4286).

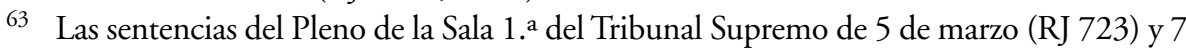
de septiembre (RJ 5303) de 2007, dictadas ambas en casos de venta múltiple, sentaron la doctrina aplicable a la calificación de la venta de cosa ajena y su relación, por un lado, con la protección registral del art. $34 \mathrm{LH}$, y, por otro, con el art. $1473 \mathrm{CC}$. El caso difiere del que aquí nos ocupa, que no es el de una venta múltiple, pero la doctrina establecida en la primera de las sentencias citadas, respecto a la aplicabilidad del art. $34 \mathrm{LH}$ a la venta de cosa ajena, es la misma que ha trascendido en la jurisprudencia ulterior aplicable al caso que aquí nos trae. En este sentido, resulta importante destacar el pronunciamiento contenido en su FJ 7: «La doctrina sobre el artículo 34 de Ley Hipotecaria que procede dejar sentada comprende dos extremos: primero, que este precepto ampara las adquisiciones a non domino precisamente porque salva el defecto de titularidad o de poder de 
dejaría también expedito el camino a la usucapión ordinaria del bien ${ }^{64}$, en su caso, si el adquirente fuese de buena $\mathrm{fe}^{65}$.

Esta es la solución por la que se inclina actualmente la doctrina mayoritaria. En cuanto a la jurisprudencia, si bien existe un cierto número de sentencias del Tribunal Supremo que vienen también acogiendo esta solución —entre ellas, la que centra nuestro interés en estas páginas— ${ }^{66}$, conviene

disposición del transmitente que, según el Registro, aparezca con facultades para transmitir la finca, tal y como se ha mantenido muy mayoritariamente por esta Sala; y segundo, que el mismo artículo no supone necesariamente una transmisión intermedia que se anule o resuelva por causas que no consten en el Registro, ya que la primera parte de su párrafo primero goza de sustantividad propia para amparar a quien de buena fe adquiera a título oneroso del titular registral y a continuación inscriba su derecho, sin necesidad de que se anule o resuelva el de su propio transmitente». Por su trascendencia, estas sentencias del Tribunal Supremo han generado diversos estudios doctrinales. Véase, por todos, el de Cuena Casas (2010: passim). Esta doctrina se reitera en pronunciamientos ulteriores: SSTS de 5 de mayo (RJ 5502) y 20 de noviembre (RJ 6933) de 2008 y 13 de noviembre de 2009 (RJ 759).

64 En este sentido se pronuncia la STS de 26 de febrero de 2008 (RJ 2819), en la que se había transmitido a los adquirentes una cuota en varios inmuebles superior a la que realmente correspondía en ellos a su transmitente. El Tribunal Supremo, tras recordar que la venta de cosa ajena no es nula, pues el poder de disposición de los transmitentes no es requisito esencial del contrato, la considera como justo título para la usucapión ordinaria por la parte compradora.

65 Como puntualiza Ragel Sánchez (2013: 872), según los partidarios de esta teoría, la falta de poder de disposición del partícipe podría superarse mediante la ratificación del negocio por parte del resto de los comuneros y, en su defecto, con la inscripción registral de la venta reuniendo los requisitos del artículo $34 \mathrm{LH}$ o con la usucapión ordinaria.

66 La misma solución se acoge también en la STS de 20 de febrero de 2004 (RJ 2061). La doctrina jurisprudencial al respecto se establece en el FJ 3, punto 3, apartado iv): «[...] en nuestro sistema jurídico el poder de disposición del transmitente no es un requisito de la validez del contrato, sino de la tradición como modo de adquirir (art. 609 CC). La validez obligacional del contrato de venta común [sic, de venta de cosa común] sin el consentimiento de todos los comuneros fue la doctrina sostenida por la sentencia 872/2012, de 15 de enero (RJ 2013, 2276), con cita de la anterior 620/2011, de 28 de marzo (RJ 2012, 5589), cuya doctrina a este respecto se reitera». Hay que precisar, no obstante, que solo la primera de estas dos sentencias que se citan como antecedentes de la doctrina que se reitera en la que aquí venimos comentando la establece con su misma claridad y rotundidad, si bien lo hace con carácter de obiter dictum. En cambio, la STS de 28 de marzo de 2012 (RJ 5589) resulta mucho menos clara y más vacilante, ya que, aunque aplica al caso la doctrina 
precisar que no puede identificarse una línea jurisprudencial unívoca, dada la sucesión de sentencias en las que se acoge una solución y la otra en fechas muy cercanas entre sí, lo que todavía impide hablar de una doctrina unificada al respecto a partir de un cierto momento.

\subsection{La conveniencia de una reforma legal y la necesidad de unificación de la doctrina jurisprudencial respecto a la calificación jurídica que ha de darse a este tipo de actos}

La situación que se ha expuesto genera inseguridad jurídica ${ }^{67} \mathrm{y}$, por ende, litigiosidad, por lo que resulta obvio que lo más deseable sería una reforma legal que aclarara de una vez por todas el tratamiento jurídico y la sanción aplicable a los supuestos de disposición del bien común por un partícipe sin contar con el consentimiento del resto de los comuneros, ya fuera la opción elegida su reconducción a la doctrina que se ha creado en torno a la atípica venta de cosa ajena ${ }^{68}$, ya fuera otra la solución preferida. Pero todos sabemos que es muy improbable que esto suceda, al menos en un futuro próximo.

de la validez de la venta de cosa ajena, considera que ello solo es posible cuando todos los comuneros «tienen interés en la decisión» (algo que no se sabe exactamente qué quiere decir), pero que ello no obsta a que se conserven los argumentos en pro de la nulidad de la disposición de la cosa común por un único partícipe, como regla general. La aplicación de la doctrina de la validez de la venta de cosa parcialmente ajena resultaría ser, así, una suerte de excepción a aquella regla general, cuya aplicación queda supeditada «al estudio de las circunstancias del caso y a la consiguiente interpretación del contrato celebrado». Cabe puntualizar, además, que el supuesto de hecho que sirve de base a esta sentencia es, en realidad, en nuestra opinión, el de una doble venta o venta múltiple. Sobre esta sentencia concluye López Frías (2013: 11) que, a pesar de haberse dictado por el Pleno de la Sala $1 .{ }^{a}$ del Tribunal Supremo, no ha zanjado los problemas relativos a la validez y eficacia de la venta de la cosa común cuando no intervienen todos los comuneros. (Murga Fernández, 2011: 8; Pérez Gurrea, 2012: 3568; López Frías, 2013: 1-3)

67 Como denuncia López Frías (2013: 6).

68 Esta parece ser la orientación dada al problema por la Asociación de Profesores de Derecho Civil (2018: 460-461) en el art. 342-6 de su Propuesta de Código Civil, relativo a la disposición de la cosa común. En su número 1 se explicita que la disposición de la cosa común —claramente ya «jurídica», pues las alteraciones materiales son objeto del precepto anterior - requiere el consentimiento de todos los comuneros, si bien la sanción ante su falta es que no se producirá la transmisión, sin perjuicio de la posibilidad de adquirir $a$ non domino, lo que, unido a las consecuencias para el tercero contratante previstas en el número 2 del propio artículo, lleva a pensar que se reputa válido el acto de disposición. 
Entretanto, lo que sí cabe reivindicar es una unificación de la doctrina jurisprudencial del Tribunal Supremo al respecto ${ }^{69}$, ya que hasta el momento ninguna sentencia del Pleno de la Sala $1 .{ }^{\mathrm{a}}$ ha dejado sentado como ratio decidendi que la calificación jurídica correspondiente al supuesto del que venimos ocupándonos aquí es la validez obligacional y no jurídico-real de estos actos, como especie o concreción de la venta de cosa ajena ${ }^{70}$. Hasta que eso suceda, seguirá habiendo base para dudar de que todos los casos de venta de cosa ajena, sean cuales sean sus particularidades, deban recibir el mismo tratamiento jurídico y, especialmente por lo que aquí interesa, que haya que ignorar abiertamente las reglas contenidas en los arts. 397 y 399 CC y desechar también una posible aplicación analógica del art. $1259 \mathrm{CC}^{71}$.

\section{EL CONTRATO DE ALIMENTOS COMO TÍTULO APTO PARA LA TRANSMISIÓN DEL DOMINIO DE CARÁCTER ESENCIALMENTE ONEROSO}

En el plano terminológico, la denominación más extendida para designar el pacto que tuvo lugar entre madre e hijas es la de «contrato de alimentos ${ }^{72}$, negocio tipificado desde el año 2003 en los arts. 1791 a 1797 CC,

69 Algo que viene reclamando la doctrina desde hace tiempo. En este sentido, por todos, véase Cuena Casas (2010: 2945).

70 Hay que precisar que la STS de 29 de noviembre de 2018 que venimos comentando aquí no es una sentencia del Pleno de la Sala $1 .^{\mathrm{a}}$ y que ninguna de las otras dos sentencias que invoca - la de 28 de marzo de 2012 y la de 15 de enero de 2013, ambas sí del Pleno de la Sala - para reiterar su doctrina comparten con ella identidad de razón. Además, en esas dos sentencias los actos dispositivos celebrados en solitario por el comunero disponente se acaban declarando, por razones diversas, como nulos de pleno derecho.

71 Ragel Sánchez (2017: 677-679) propone la aplicación del art. 1259 CC, la consideración de que el contrato es nulo o incompleto en tanto no concurra el consentimiento de todos los comuneros, para todos los casos en que uno solo de ellos dispone de la totalidad del bien o derecho común perteneciente a la comunidad posganancial.

72 En la sentencia que aquí nos trae, se encuentran expresiones diversas para hacer referencia al pacto celebrado entre madre e hijas que origina el litigio posterior: así, el demandante y las sentencias de instancia se refieren a él como «contrato de cesión de nuda propiedad a cambio de alimentos»; las recurrentes en casación lo califican como "contrato atípico de cesión a cambio de alimentos», al tiempo que invocan la infracción por la sentencia de instancia de los arts. 1802 a 1808 CC, y el Tribunal Supremo, por su parte, se refiere en su argumentación a un «contrato de transmisión de bienes a 
unos preceptos que, por lo tanto, estaban ya en vigor y constituían la ley aplicable a ese acuerdo que se había celebrado en 2007 y en zona de derecho común ${ }^{73}$. Causa cierto estupor que ninguna de las sentencias de instancia hagan referencia alguna a estos preceptos legales ${ }^{74}$, pero más llamativo aún es que tampoco la de casación aluda a ellos en ningún momento, ni siquiera al abordar el segundo motivo del recurso que denuncia contradictoria y simultáneamente la infracción de la jurisprudencia relativa "al contrato atípico de alimentos» y la infracción de los arts. 1802 a $1808 \mathrm{CC}^{75}$.

Lo importante, en cualquier caso, es que el Alto Tribunal parte de la recta consideración del negocio de autos como un contrato de alimentos, en cuya virtud el alimentante se compromete a proporcionar al alimentista una asistencia tan completa como precise, a cambio de que el propio alimentista o una tercera persona a su favor le transmita la propiedad de todo tipo de bienes muebles o inmuebles o la titularidad de algún derecho transmisible. Según la

cambio de prestaciones asistenciales» (FJ 3, punto 3, razón 1. ${ }^{a}$ ), decantándose de este modo por una denominación que, si bien no es la de uso más frecuente o consolidado, pone el énfasis en la descripción de las prestaciones involucradas en el negocio litigioso.

73 La regulación legal del contrato de alimentos fue introducida en el Código Civil por la Ley 41/2003, de 18 de noviembre, de Protección patrimonial de las personas con discapacidad y de modificación del Código Civil, de la Ley de Enjuiciamiento Civil y de la normativa tributaria con esta finalidad.

74 Tampoco menciona Vela Sánchez (2019: 8-9) la denominación más habitual del contrato de alimentos ni los preceptos que lo regulan en el Código Civil.

75 El contrato de alimentos no es atípico y los preceptos mencionados regulan la renta vitalicia, así que el planteamiento del motivo es claramente defectuoso, aunque haya similitudes entre ambos contratos aleatorios que hacen que en alguna ocasión se dude de cuál de ellos es el que se ha concertado en un caso particular. En este sentido, y sobre su distinción, véanse SAP de Barcelona de 26 de noviembre de 2018 (JUR 330817) y SAP de Pontevedra de 5 de junio de 2017 (JUR 174672). Aunque el Tribunal Supremo no otorga a este defectuoso planteamiento del motivo de casación trascendencia alguna, creemos que podría haber aplicado la regla da mihi factum, dabo tibi ius, puntualizando que el régimen jurídico aplicable al contrato de alimentos se contiene en los arts. 1791 a 1797 CC. Ello no hubiera hecho decaer el segundo motivo del recurso, ya que, tal como se aborda en la sentencia, lo que parece determinar su admisión es la invocada «infracción de la jurisprudencia relativa al contrato», la cual, obviamente, y tras más de tres lustros de vigencia de dicho régimen legal, es también una jurisprudencia emanada al hilo de aquellos preceptos. Además, aunque el motivo hubiese decaído, el tercero de los que fundamentan el recurso de casación vuelve a plantear el error en torno a la gratuidad del contrato de alimentos como punctum candens del proceso, a los efectos de la aplicabilidad del art. $34 \mathrm{LH}$. 
opinión mayoritaria, se trata de un contrato de carácter consensual ${ }^{76}$, bilateral y sinalagmático ${ }^{77}$, de tracto continuo o sucesivo, aleatorio, naturalmente vitalicio $^{78} \mathrm{y}$, por supuesto, oneroso, como se concluye en la sentencia que nos ocupa.

La finalidad traslativa del contrato de alimentos, ya sea del derecho de propiedad de los bienes del cedente, ya sea de la titularidad de los derechos que conformen su prestación, parece fuera de toda duda ${ }^{79}$. El contrato de alimentos es, pues, en este sentido, un título válido a tales efectos. Dicho elemento parece destacarse especialmente en el art. $1791 \mathrm{CC}$, donde el legislador emplea literalmente la palabra transmisión $n^{80}$. Así, la doctrina considera que la obligación del cedente no queda cumplida hasta que dicha transmisión se produzca, lo que ex art. 609 CC sucederá tan solo cuando confluyan el título - el contrato- y el modo que corresponda a la naturaleza de los bienes

76 La opinión mayoritaria, que compartimos, considera que el contrato de alimentos tiene carácter consensual, de modo que la entrega efectiva del capital por parte del cedente no es elemento constitutivo del mismo, ni requisito para su perfección. Al respecto, véanse, por todas, las consideraciones de Moreno Martínez (2013: 12261) y Castilla Barea (2017: 284), con detalle de los autores que comparten este criterio.

77 Lo que significa que las prestaciones de las partes son interdependientes aunque no puede exigirse una absoluta equivalencia entre ellas, ni tampoco que su valoración pueda regirse por idénticas reglas, dado que estas notas han de conciliarse con el carácter eminentemente aleatorio del contrato de alimentos. La doctrina afirma mayoritariamente el carácter bilateral y sinalagmático del contrato de alimentos, del que deriva la posibilidad de resolverlo por incumplimiento o por imposibilidad sobrevenida de la prestación (ex arts. 1124, 1795 y 1796 CC). Véase al respecto Castilla Barea (2017: 284-285).

78 Afirmando la mayoría de estos caracteres, véanse la SAP de Sevilla de 25 de febrero de 2016 (AC 2016, 1088) y la SAP de Pontevedra de 5 de junio de 2017 (JUR 174672).

79 Para evitar el equívoco que puede producirse al hablar de contratos traslativos del dominio u otros derechos reales, dada la eficacia meramente obligacional del contrato en nuestro derecho, merced a la operatividad del sistema de título y modo, suele puntualizarse que existen contratos con finalidad traslativa, cuyo paradigma es la compraventa. En este mismo sentido, véase Domínguez Martínez (2013: 52). Puntualiza Fernández Chacón (2018: 53) que, a pesar de su eficacia puramente obligacional, estos contratos intervienen de forma decisiva en el íter transmisivo, al albergar las respectivas voluntades negociales de transferencia y adquisición.

80 De hecho, el vigor de esta obligación de transmitir la titularidad de los bienes o derechos cedidos es tal que algún autor ha sostenido el carácter real del contrato de alimentos, como antes de 2003 lo hiciera alguna jurisprudencia respecto al contrato atípico de vitalicio. No obstante, se trata de una posición minoritaria en la doctrina y la jurisprudencia, como explicamos en otro lugar. Véase Castilla Barea (2017: 284 y 302). 
o derechos cedidos en cada caso - entrega material de la cosa, otorgamiento de escritura, entrega de los títulos de pertenencia, etc. —, y que al contrato de alimentos le resultan aplicables por analogía las obligaciones propias de la compraventa en materia de conservación de la cosa, saneamiento por vicios ocultos y por evicción y gastos ${ }^{81}$. Esta última conclusión - la de que cabe aplicar al contrato de alimentos, por analogía, normas propias del contrato de compraventa- sería insostenible si el contrato regulado en los arts. 1791 CC no fuera esencialmente oneroso como, por su parte, afirma reiteradamente la jurisprudencia menor ${ }^{82}$.

Por lo que atañe a su onerosidad, parece claro que ni el alimentante ni el alimentista dan o hacen algo gratuitamente o por nada, sino que, antes al contrario, cada uno de ellos se obliga en contemplación de la prestación de su contraparte. Parafraseando la definición de causa de los contratos onerosos que efectúa el art. $1274 \mathrm{CC}$, cabe señalar que para el alimentante la causa del contrato es la transmisión a que se obliga el alimentista, en tanto que para este la causa del contrato es la prestación asistencial que le promete el alimentante. La importancia de este intercambio de prestaciones entre las partes contratantes como base del negocio queda bien expuesta a tenor de la letra del propio art. $1791 \mathrm{CC}$, que no duda en emplear las palabras a cambio de, verdadera expresión del sinalagma contractual ${ }^{83}$. Y es que, en efecto, aunque algunas otras características del mismo resultan discutidas ${ }^{84}$, no cabe duda de la onerosidad del contrato de alimentos contemplado en el art. $1791 \mathrm{CC}$, un carácter no natural, sino esencial del negocio ${ }^{85}$, y que, de no concurrir, desnaturaliza el propio contrato y determina la inaplicabilidad del régimen legal que el Código Civil le adosa ${ }^{86}$.

81 En este sentido, véase por todos, Moreno Martínez (2013: 12272).

82 Véanse en este sentido, entre las más recientes, la SAP de Madrid de 13 de marzo de 2018 (JUR 155493) y la SAP de Córdoba, de 11 de diciembre de 2018 (JUR 66862). La STS de 20 de noviembre de 2017 (RJ 5099) proclama también esa esencial onerosidad, pero no constituye jurisprudencia por sí sola.

83 Carácter sinalagmático que expresamente afirma la SAP de Santa Cruz de Tenerife de 9 febrero 2015 (JUR 2015, 221231).

84 En lo tocante al concepto, caracteres del contrato de alimentos y argumentos que invoca la doctrina en el debate sobre algunos de sus rasgos distintivos, véase nuestra exposición más reciente, Castilla Barea (2017: 283-292 y 302).

De acuerdo, véase Moreno Martínez (2013: 12262).

86 En este sentido, es importante tener en cuenta que la jurisprudencia viene reconociendo que el pacto de alimentos celebrado por las partes contratantes puede tener caracteres muy diversos en cada caso, de suerte que en virtud del principio de la autonomía de la voluntad (art. 1255 CC) se pueden asumir obligaciones de 
Además, es importante destacar que, ante la duda sobre el carácter oneroso o gratuito que pueda presentar el pacto en un caso concreto y, más aún, si tiene cierta complejidad, el Tribunal Supremo ha sostenido que no procede una interpretación a favor de la menor transmisión de derechos, lo que resulta a efectos prácticos en una interpretación restrictiva de la gratuidad del contrato de alimentos ${ }^{87}$.

Por lo que aquí interesa, esta onerosidad del contrato de alimentos resulta vital para que pueda invocarse por las hermanas adquirentes la protección del art. $34 \mathrm{LH}$.

\section{LA BUENA FE DEL TERCERO HIPOTECARIO. SU APRECIACIÓN EN EL CASO DE AUTOS}

Como ha destacado la jurisprudencia:

[...] la buena fe constituye uno de los presupuestos de la protección registral, pues justifica que el tercero adquirente resulte protegido en la medida en que ha contratado confiando en la información ofrecida por el Registro. Si esta razón quiebra, y el tercero es conocedor de la inexactitud del Registro respecto a la realidad jurídica, la especial protección registral carece de justificación ${ }^{88}$.

alimentos voluntarios o convencionales que sean tanto gratuitas como onerosas, así como adaptar a las necesidades del caso concreto las demás características del pacto. Nuestro Alto Tribunal ha sido especialmente claro a este respecto en la STS de 20 de noviembre de 2017 (RJ 5099): «Al amparo del principio de autonomía de la voluntad (art. 1255 CC), cabe que las partes pacten una variedad heterogénea de tipos de contratos en función de sus intereses: contratos de naturaleza personal o real, con causa onerosa o gratuita, a cambio de contraprestación o sin ella y durante cualquier espacio de tiempo» (FJ 5). Ahora bien, ello no obsta a que la libertad de configuración del negocio elegido en cada caso tenga como consecuencia la aplicación del régimen jurídico que le resulte más adecuado en función de la naturaleza jurídica de la convención. De acuerdo con ello, es evidente, en primer lugar, que el negocio configurado en los arts. 1791 CC es un contrato esencialmente ( $\mathrm{y}$ no naturalmente) oneroso, y, en segundo lugar, que solo el pacto que presente tal naturaleza puede considerarse como título hábil para proporcionar al cesionario adquirente tanto la protección del art. $34 \mathrm{LH}$ como la inmunidad de su derecho frente a posibles pretensiones de inoficiosidad.

87 En este sentido, véase la STS de 20 de noviembre de 2017 (RJ 5099), FJ 5.

88 El párrafo transcrito se ha extraído del FJ 2 de la STS de 12 de enero de 2015 (RJ 185). 


\section{EL CONCEPTO DE BUENA FE REGISTRAL}

Siendo la buena fe un concepto jurídico indeterminado de gran presencia en otros ámbitos del derecho civil para los que también ha tenido que precisarse su significado y habida cuenta de la complejidad y variedad de matices que presentan las situaciones que se dan en la práctica hasta llegar a una adquisición a non domino, es comprensible que la jurisprudencia haya debido precisar la noción de buena fe registral, en cuanto que presupuesto esencial de la tutela del tercero hipotecario ${ }^{89}$. Y, así, la doctrina jurisprudencial más reciente asume la polisemia del concepto de buena fe, que, en su dimensión negativa, viene a significar la ignorancia o desconocimiento de la inexactitud del Registro en tanto que, desde una perspectiva o dimensión positiva, se identifica con la creencia o convicción de que el tradens es el titular real y puede disponer del derecho ${ }^{90}$, pero, partiendo de esta dualidad posible en cuanto a su estado sicológico ${ }^{91}$, viene exigiendo al adquirente cierta dosis de

89 Parece claro que la buena fe registral es una concreción o manifestación del principio general de buena fe consignado en el art. 7.1 CC, que se proyecta en formas diversas en muchas instituciones jurídico-civiles y que se explicita en otros muchos preceptos, como el 434, 1473, 1950 y ss., etc., y, por lo que aquí interesa, también en el art. 34 LH. Así lo afirma la STS de 11 de diciembre de 2013 (RJ 4350), cuando destaca el "papel rector que debe jugar el principio de buena fe como exigencia en el ejercicio de los derechos, artículo 7.1 del Código Civil, referenciado en el cumplimiento de los criterios de ética social en las relaciones jurídicas y su natural proyección en los deberes de rectitud, honradez y lealtad en los tratos y en su consecuente interpretación y ejecución.

En efecto, una aplicación del citado principio, formulado con este carácter general, [...] resulta aplicable al tercero del artículo 32 de la Ley Hipotecaria y también, aunque resulta presumida, al tercero hipotecario del artículo 34 del mismo Cuerpo Legal» (FJ 2). No obstante, Méndez González (2018: 14 y 39-40) desmiente este planteamiento, al considerar que el concepto de buena fe del art. $34 \mathrm{LH}$ es el que el legislador ha querido precisar para su concreto ámbito de aplicación y que no tiene por qué ser determinado o establecido por el juez.

Evidentemente, la formulación jurisprudencial de la buena fe en sentido negativo o como estado de ignorancia se inspira claramente en el concepto de poseedor de buena fe del art. $433 \mathrm{CC}$, como aquel «que ignora que en su título o modo de adquirir exista vicio que lo invalide», en tanto que la dimensión positiva de la buena fe se enuncia como trasunto de la que adorna al poseedor ad usucapionem del art. $1950 \mathrm{CC}$ : «La buena fe del poseedor consiste en la creencia de que la persona de quien recibió la cosa era dueño de ella, y podía transmitir su dominio».

91 En este contexto, precisa García-Ripoll Montijano (2015: 2): «Dentro de los Derechos reales, la buena fe aparece en el CC como estado psicológico del sujeto: a) que 
diligencia en su comportamiento o actitud a la hora de verificar que la realidad material de la finca que se pueda comprobar al margen del Registro no se contradice abiertamente con la información que pregonan los asientos registrales, fundando una suerte de duda razonable acerca de la posible existencia de una discordancia entre estos y la realidad jurídica material del inmueble que podría enervar la presunción de su buena fe ${ }^{92}$. Parece, así, haberse producido una evolución ${ }^{93}$ en la configuración de la buena fe exigible al tercero

cree que le corresponde el derecho a poseer o ius possidendi, a efectos de liquidación de las situaciones posesorias (arts. 451 y ss.); b) que cree que ha realizado una adquisición del titular y/o legitimado para disponer, a efectos de la usucapión ordinaria (arts. 433 a 445, 1940, 1950, 1951, 1955 y 1957); c) que cree que ha adquirido del titular y/o legitimado para disponer, en relación con las adquisiciones a non domino de los arts. $464 \mathrm{CC} \mathrm{y} 34 \mathrm{LH}$; d) que cree que es el primero al que se ha realizado una venta (art. 1473); e) en los distintos supuestos de accesión, además de en el de accesión invertida, reconocida por el TS; se trata normalmente de la creencia de que el terreno o los materiales con los que se trabaja son propios (arts. 360 a 365 y 375 a 383)».

92 No obstante, hay ocasiones en las que ni siquiera es preciso llegar a cuestionarse si el adquirente debía o no haber realizado tal o cual pesquisa, porque los hechos probados demuestran por sí solos y a las claras que no estaba en la situación psicológica propia de la buena fe, como sucede en el caso enjuiciado por la STS de 13 de mayo de 2013 (RJ 3699). Llama la atención, no obstante, que en esta sentencia parece negarse que la buena fe, no ya para el caso de autos, sino con carácter general, pueda exigir cualquier tipo de conducta activa, cuando eso es precisamente lo que había afirmado la sentencia de apelación que también había apreciado la mala fe de la sociedad adquirente: «El concepto de buena fe, en el campo de los derechos reales, no es un estado de conducta como ocurre en las obligaciones y contratos sino de conocimiento, ajeno a las maniobras y al engaño: así, sentencias de 17 julio 1999 (RJ 1999, 6771), 22 diciembre 2000 (RJ 2000, 10136), 18 diciembre 2007. Es el sentido negativo de la buena fe, como elemento intelectivo de desconocimiento o ignorancia del error, al que se suma el elemento positivo de creencia o confianza en la exactitud del Registro de la Propiedad: así se ha expresado la jurisprudencia desde la antigua sentencia de 9 julio 1900 hasta las más recientes de 23 mayo 2002, 24 julio 2003, 2 abril de 2004, pasando por la contundente de 2 julio 1965" (FJ 2). Igual planteamiento se reproduce, aunque con un cierto mimetismo, pues en el caso enjuiciado no se debatía especialmente si existía buena o mala fe del adquirente ni en qué consistía esta, en la STS de 11 de octubre de 2014 (RJ 4881), FJ 2.

93 Sin embargo, estamos de acuerdo con García-Ripoll Montijano (2015: 6) cuando puntualiza que no hay un "reforzamiento» reciente del concepto jurisprudencial de la buena fe, sino que la exigencia de que el estado psicológico de creencia en la regularidad de la adquisición se acompañe de una cierta diligencia es «algo que el TS viene 
hipotecario ${ }^{94}$, que ha transitado desde la llamada "concepción psicológica» a la llamada "concepción ética», predominante hoy en la doctrina jurisprudencial ${ }^{95}$ y científica.

Particularmente expresiva al respecto de cuanto se acaba de exponer resulta la STS de 12 de enero de 2015 (RJ 185) que resume así la cuestión:

En el plano de la configuración de la buena fe en el proceso adquisitivo debe señalarse que se han desarrollado dos líneas o perspectivas de razonamiento en liza. Conforme a la primera, la idea o noción de buena fe responde a un puro estado psicológico o psíquico del tercero adquirente en orden a la creencia de que el titular registral es el verdadero dueño de la cosa y ostenta un poder de disposición sobre la misma. De forma que la ignorancia o el equivocado conocimiento de la realidad jurídica no desvirtúa la protección registral otorgada con base en esta creencia acerca de la legitimidad de transmisión realizada. Por contra, para la segunda línea de configuración, que requiere la convicción de no lesionar legítimos derechos o intereses ajenos, la noción de buena fe responde a una actuación diligente conforme a unos criterios o pautas de comportamiento que resulten socialmente aceptados; de ahí que, a diferencia de la anterior concepción, no sea suficiente padecer cualquier tipo de error, sino solo el error que, según las circunstancias, sea excusable, esto es, que no se hubiera vencido actuando diligentemente. Paralelamente, y con independencia de la concepción escogida, la buena fe también puede ser determinada, directamente, con referencia al conocimiento mismo (scientia) por el tercer adquirente de la razón o causa que obsta la legitimidad de la transmisión en el momento de perfección del negocio adquisitivo, de forma que pierde la protección otorgada. (FJ 2, la negrita es nuestra).

reconociendo desde hace muchas décadas». Cita en apoyo de esta conclusión algunas sentencias del Alto Tribunal partiendo de la de 30 de enero de 1960 (RJ 895).

Sobre la evolución del concepto de buena fe registral, su presunción y el momento en que ha de apreciarse, véase Domínguez Luelmo (2016: 561-567).

95 STS 11 de diciembre de 2013 (RJ 4350): «Llegados a este extremo, también hay que profundizar desde el citado principio general de buena fe, ya como aplicación concreta del mismo, o bien como fundamento informador, que su conexión con la protección registral comporta desde su concepción ética y social un canon básico de conducta diligente o de conocimiento que excede a la mera creencia de un hecho o situación como puro estado psicológico, de forma que la protección registral no resulta aplicable cuando la ignorancia o desconocimiento, ya de la inexactitud del Registro, o bien de los vicios o defectos que afecten a la titularidad del propietario, es imputable a la mala fe o negligencia del adquirente que conoció o debió conocer dicha irregularidad ante hechos o indicios claros, manifiestos o inequívocos al respecto. (SSTS de 25 octubre de 1999 (RJ 1999, 7623), 8 marzo de 2001 (RJ 2001, 3975) y 11 octubre de 2006 (RJ 2006, 6693), entre otras)» (FJ 2). 
Como puede apreciarse, en las líneas que hemos destacado en negrita, el Tribunal Supremo a la hora de establecer en qué consiste la buena fe del adquirente y si a este le es exigible algo más que solo pensar y confiar en la información que publica el Registro (verbos que cabe relacionar con el estado psicológico, tanto de creencia como de ignorancia, en que, sin duda, consiste la buena fe), pone el acento en un aspecto que siempre ha latido en el conflicto derivado de una adquisición a non domino, pero cuya importancia se suele minimizar, y es que esa protección que el derecho le brinda a través de la fe pública registral se materializa a costa del sacrificio definitivo de «legítimos derechos o intereses ajenos», y que, precisamente por ello mismo, se puede y se debe exigir una cierta diligencia al adquirente en orden a la comprobación o verificación de que la realidad material perceptible del inmueble no desmiente claramente la información registral, o no proporciona indicios racionales, o no funda suficientemente la duda, respecto de que pueda existir una discordancia entre la realidad jurídica de la finca y lo que se cree o se ignora respecto de esa realidad ${ }^{96}$.

Obviamente, este planteamiento no puede llevarse al extremo de que el tercero adquirente deba desconfiar por principio de lo que pregonan los asientos registrales y lanzarse en todo caso a efectuar todo tipo de comprobaciones sobre cualquier eventual titularidad o expectativa de derecho al margen del Registro que pueda imaginarse, para descartar con toda seguridad que existan sobre el inmueble que pretende adquirir, pues ello sería tanto como privar de eficacia a la fe pública registral (y, en su caso, también al art. $32 \mathrm{LH}$ ) y carecería de todo sentido. Lo que significa es que si el adquirente aprecia indicios racionales o es informado de la existencia de derechos no inscritos sobre una finca que se afirma libre de ellos, o de circunstancias que limitan o condicionan la titularidad del tradens, no le bastará con mantener una actitud pasiva y alegar sin más que creía firmemente en la información registral o que no tenía una constancia plena de la realidad de aquellos derechos o limitaciones, sino que deberá desplegar una mínima diligencia, siempre adecuada al caso concreto, para disipar con cierto fundamento esas dudas o para fortalecer esa creencia. En este sentido, al menos, interpretamos la advertencia que efectúa

96 Por ejemplo: el Registro indica que la finca está libre de toda carga o gravamen y, sin embargo, en su visita se aprecia claramente un carril de rodada que la atraviesa, dando acceso a la carretera a la finca colindante. En esta situación, si el propietario de la finca colindante alega la existencia de una servidumbre de paso sobre el predio que se pretende adquirir libre de cargas, al tercero adquirente debería exigírsele una comprobación mínima sobre la efectiva existencia de ese derecho. Piensa en el mismo supuesto enervante de la fe pública registral García-Ripoll Montijano (2015: 6). 
el Alto Tribunal en la misma sentencia ya citada cuando sostiene que sobre el accipiens pesa la carga ética de desplegar una "diligencia "básica" que haga, en su caso, excusable el error que pudiera sufrir el adquirente respecto del conocimiento de la realidad del curso transmisivo operado y, en su caso, de la discordancia con la información ofrecida por el Registro", para puntualizar a continuación que no se le va a requerir en abstracto «el examen de cualquier vicio, defecto o indicio que pudiera afectar a la validez y eficacia del negocio dispositivo realizado, sino que debe proyectarse y modularse, necesariamente, en el marco concreto y circunstancial que presente la impugnación efectuada por el titular extraregistral a tales efectos».

Cabe, además, señalar que esta concepción «ética» o «reforzada» de la buena fe exigible al adquirente no solo se viene exigiendo en el ámbito de las adquisiciones a non domino del art. $34 \mathrm{LH}$, sino también para la adquisición de los derechos reales por medio de la usucapión ordinaria ${ }^{97}$.

\section{LA PRESUNCIÓN DE LA BUENA FE REGISTRAL. ACTIVIDAD PROBATORIA}

El art. $34 \mathrm{LH}$ exige la buena fe del adquirente para protegerle en su adquisición, favoreciendo su apreciación mediante la presunción de que concurre siempre «mientras no se pruebe que conocía la inexactitud del Registro».

97 Véase en este sentido el FJ 3 de la STS de 8 de octubre de 2014 (RJ 5784). En el caso de autos se había producido una compraventa de bienes hereditarios por un legatario de la causante, sin contar con el consentimiento del resto de los coherederos. Con carácter de obiter dictum se alude al carácter defectuoso del título desde el punto de vista del poder de disposición del vendedor, pero la cuestión se resuelve sobre la base de analizar los requisitos de la usucapión ordinaria que alegaba la parte compradora y que no prosperó por entender el Alto Tribunal que carecía de la buena fe necesaria. Sobre esta sentencia, véase el comentario de García-Ripoll Montijano (2015: passim). El autor (ibid:: 7-8) destaca que el Tribunal Supremo, apartándose del criterio de los órganos de instancia, enmiende su apreciación sobre la buena o mala fe de la adquirente, al tratarse de una cuestión de hecho que debiera quedar incólume en casación, y afirma que hasta esta sentencia, salvo error por su parte, nunca había enmendado el criterio de la instancia al respecto de la buena o mala fe del adquirente ni en el seno de la doble venta, ni en el de la usucapión ordinaria, ni en el de las adquisiciones registrales a non domino, citando un amplio conjunto de sentencias en este sentido. A su entender, ello solo puede hacerlo el Alto Tribunal en el seno del recurso extraordinario por infracción procesal cuando la apreciación de la prueba por parte de la Audiencia Provincial haya sido arbitraria, irracional o ilógica, con base en el art. 469.4. ${ }^{\circ}$ LEC. Lo consignamos porque es algo que también sucede en la STS de 29 de noviembre de 2018 que venimos considerando. 
Esta presunción de buena fe, que explicita para el ámbito hipotecario la que rige como principio general en el terreno del derecho civil "puro» ex art. $434 \mathrm{CC}$, traslada al que pretende tener derechos sobre el inmueble adquirido — verus dominus en el caso paradigmático - la carga de probar que el adquirente conocía la existencia de una contradicción entre la situación jurídica de la finca que pregonan los asientos registrales y la realidad extrarregistral, conforme a la cual cabría sostener la existencia de otros derechos no publicados o de una situación diversa en cuanto a la titularidad y alcance de los derechos inscritos. Esta distribución de la carga de la prueba parece coherente con el principio de facilidad probatoria consignado en el art. 217 LEC, puesto que, de no regir la presunción y de ser el adquirente quien hubiera de acreditar su buena fe, la prueba se referiría a un hecho negativo, cual es el de su desconocimiento de la inexactitud registral, un estado psicológico de ignorancia que resulta prácticamente imposible de probar. Por el contrario, quien pretenda enervar la buena fe del tercero puede tener a su alcance medios para demostrar que conocía esa inexactitud o que, cuando menos, se le había advertido suficientemente sobre la misma, generando en el tercero una duda razonable respecto a la exactitud del Registro que podría justificar una especial diligencia por su parte a la hora de investigar la veracidad de lo que se le advierte.

\section{LA BUENA FE DE LAS ADQUIRENTES EN EL CASO DE AUTOS}

Como ya se ha podido adelantar, el Tribunal Supremo considera en la sentencia que viene centrando nuestro interés que en las hermanas adquirentes de la vivienda litigiosa concurría el tan preciado requisito, conclusión a la que llega incluso tras aplicar la llamada "concepción ética» de la buena fe y al considerar que no se desvirtuó su presunción mediante prueba alguna por parte de su hermano y actor. Conviene destacar que, a pesar de que no hay mayor desarrollo al respecto en la sentencia de apelación, la Audiencia Provincial concluyó al igual que el Juzgado de Primera Instancia que «tampoco existiría la buena fe en las adquirentes que conocían la naturaleza de domicilio conyugal de la vivienda ya que la misma fue adquirida constante el matrimonio habiendo vivido allí desde hacía más de cincuenta años» ${ }^{98}$.

Por lo que respecta a los razonamientos que llevan al Alto Tribunal a estimar la buena fe de las recurrentes en casación, merece la pena reproducir el alegato de su defensa, que se contiene en el tercer motivo del recurso, en

98 El fragmento, extraído del FJ 3 de la SAP de Alicante de 14 de abril de 2016 (JUR 148112), se transcribe también en lo esencial en el FJ 1, punto 4, de la STS de 29 de noviembre de 2018 (RJ 5395). 
el cual, tras invocar la infracción del art. $34 \mathrm{LH}$ en lo concerniente a la presunción de la buena fe y del concepto jurisprudencial de la misma fijado en la STS de 12 de enero de 2015 (RJ 185) a la que antes nos hemos referido, apunta: «Por otro lado, se exige de mis mandantes unos conocimientos sobre derecho y normas que son en sí mismos jurídicamente discutibles, e igualmente una supuesta diligencia que va mucho más allá del concepto de buena fe fijado en dicha doctrina».

Y, en efecto, la aceptación de este planteamiento de partida parece subyacer en la decisión de la Sala, ya que en la argumentación de la misma resulta capital para apreciar la buena fe de las adquirentes la complejidad jurídica de todo el proceso de adquisición de la vivienda litigiosa, muy dilatado en el tiempo, y que culminó con el otorgamiento por parte de la Administración competente de una escritura pública en la que figuraba su madre como única propietaria. Para el Alto Tribunal resulta muy relevante que la adquisición de la propiedad por parte de la cedente tradens se documentase en un instrumento público (título, en sentido formal) otorgado por una Administración pública y que la adquisición se produjera como consecuencia de un sistema que en el propio documento se calificaba como de «acceso diferido de la propiedad» (título, en sentido material), una cuestión que no es objeto de particular discusión en sede casacional, pero que sí centra buena parte del discurso de la sentencia de apelación, ya que resultaba fundamental para establecer el carácter ganancial o privativo del bien litigioso. En dicha sentencia de apelación se concluye que dicho sistema consistía, básicamente, en una compraventa con precio aplazado y pacto de reserva de dominio, en cuya virtud la propiedad no se adquiere hasta el total desembolso del precio pactado, si bien, una vez abonado este, los efectos del negocio se retrotraen al momento de la perfección del contrato ${ }^{99}$. Evidentemente, de la aplicación de este planteamiento resulta que la adquisición se produjo para la sociedad de gananciales por efecto de esa retroacción, pero el Tribunal Supremo considera que la apariencia de titularidad única de la madre cedente es lo suficientemente robusta como para fundar el error excusable de las adquirentes a este respecto, ya que la mera referencia a un «sistema de acceso diferido de la propiedad», más que engendrar la duda, fortalece la creencia de que la adquisición se produjo en 1985, catorce años después de la muerte del padre y que, por tal razón, la Administración pública competente otorgaba escritura de propiedad tan solo a favor de la madre, como única propietaria de la vivienda ${ }^{100}$.

99 Así se extrae de los FF. JJ. 2 y 3 de la SAP de 14 de abril de 2016, JUR 148112.

100 Véase la argumentación completa en el FJ 3, punto 3, de la STS de 29 de noviembre de 2018 (RJ 5395). 
Aunque el Tribunal Supremo no hace especial hincapié en este extremo, hay que decir claramente que el error que comete la Administración pública cuando en la meritada escritura de 1985 atribuye la propiedad exclusiva de la vivienda a la madre de los litigantes no pareció ser detectado por el notario autorizante y tampoco generó oposición alguna por parte del registrador cuando se le solicitó la inscripción del título ${ }^{101}$, consagrándose de este modo una auténtica «inexactitud del Registro» por cuanto, desde el momento de la inscripción, la fe pública registral amparaba una titularidad jurídico-real discordante con la que resultaría de la aplicación de las reglas del derecho civil puro, en cuya virtud en 1985 la titularidad del bien correspondía en absoluto proindiviso a todos los partícipes en la comunidad posganancial y en la comunidad hereditaria generadas por la muerte del esposo y padre, y, obviamente, la madre cedente carecía del poder de disposición de la vivienda que su titularidad registral hacía suponer.

Así las cosas, y dado que el Tribunal Supremo dice en la propia sentencia hacer aplicación de la llamada "concepción ética» de la buena fe, que exige que la ignorancia del adquirente respecto del defecto de titularidad del causante no se derive de su propia negligencia, hay que precisar que ninguna circunstancia de hecho, propia de la situación material de la finca y externa a la realidad registral, contradecía tampoco la titularidad de la madre, que vivió en el piso hasta su muerte, y, además, en compañía de las hijas demandadas, sin que hasta la interposición de la demanda del hijo y hermano nadie hubiese contradicho la legitimidad de esa situación. Por tanto, la diligencia específica y adicional de las adquirentes que cabría imaginar para aclarar la verdadera situación jurídica del inmueble en este concreto supuesto habría sido una diligencia no de comprobación material, ni de verificación mínima del título que permite apoyar una situación posesoria, sino de orden técnico-jurídico, que tendría que haberse basado en una desconfianza, difícilmente sustentable para un adquirente medio, que tendría que haberlas hecho dudar, primero, de la corrección de la actuación de la Administración a la hora de otorgar el título de compraventa a favor de la madre; segundo, respecto del control notarial del contenido de la escritura y de la titularidad en ella consignada, y, finalmente,

$\overline{101}$ Lo cual es lógico si se parte de la base de que al registrador le corresponde tan solo analizar la legalidad extrínseca del título y la coherencia del tracto sucesivo de los derechos inscritos con lo que resulta de los asientos registrales precedentes sobre la misma finca. En este sentido, véanse, entre otras, la STS de 24 de octubre de 2000 (RJ 9220) y la RDGRN de 31 de mayo de 2018 (RJ 2686), que aclara la función del notario y del registrador en el control de legalidad intrínseca y extrínseca de los títulos públicos. 
respecto de la extensión del derecho de una titular registral a la que las adquirentes, sin duda, habían podido considerar durante toda su vida «dueña» (en sentido amplio y coloquial) de la vivienda que les transmitía. Una duda así, una desconfianza así, solo podría partir o bien de su siembra por parte de una pretensión exteriorizada por alguno de los comuneros - el hermano demandante, por ejemplo - antes de la celebración del contrato de alimentos ${ }^{102}, \mathrm{o}$ bien de un conocimiento técnico-jurídico del derecho por parte de alguna de las adquirentes que le hiciera revisar con los ojos de un profesional la historia jurídica de la titularidad que se les pretendía transmitir y que no resulta exigible. No en balde, se da la paradoja de que las adquirentes demandadas son, a su vez, y por las circunstancias peculiares de este caso, comuneras despojadas de su titularidad por la disposición unilateral de la madre, partícipes también de las mismas comunidades que pesaban sobre el bien cedido en el contrato de alimentos, y ello, aunque, como resulta obvio, tal despojo no derivase finalmente en una situación perjudicial para ellas, como sí hubiera ocurrido en el supuesto de que la madre hubiese cedido el inmueble a un extraño, ajeno a dicha situación de comunidad.

102 Aunque no hay ninguna información ni en la sentencia de apelación ni en la de casación que abone esta impresión personal, es posible que el actor se preocupara de sus eventuales derechos sobre la finca solo tras la muerte de su madre y por considerarse heredero de ella. Es posible que siempre hubiese confiado en la naturaleza ganancial del piso y que hubiese permitido sin más la situación de indivisión en atención a la vida de su madre, para que esta disfrutara de una posesión pacífica hasta el fin de sus días; pero también es posible que hasta la muerte de ella ignorase que tenía algún derecho sobre el inmueble, derivado de su condición de heredero de su padre, y que por eso no hubiese tomado la precaución — dado que sus hermanas también vivían en el citado inmueble - de anotar preventivamente su derecho $e x$ art. 42.6. ${ }^{\circ}$ LH. Puede ser que solo a raíz de la muerte de su madre hubiese averiguado, profundizando en la historia jurídica de la finca, el carácter ganancial de la vivienda, o puede que tal naturaleza estuviera asumida, en el plano de los hechos, por todos los hermanos y que todos ellos de consuno hubieran acordado mantener la situación de comunidad hasta la muerte de la madre. Sea como fuere, lo cierto es que el actor no aportó prueba alguna de que nunca ningún comunero intentara hacer aflorar su situación en el Registro de la Propiedad, ni tampoco de que sus hermanas demandadas tuvieran conocimiento, como él mismo, de la falta de titularidad plena y exclusiva de su madre, ni a partir de cuándo la conocieron, por lo que la presunción de su buena fe a la hora de celebrar el contrato de alimentos que fundamentaba su adquisición ex art. $34 \mathrm{LH}$ no podía decaer sobre la base de una hipotética exigibilidad de un eventual conocimiento técnico y profundo del derecho aplicable al caso, que no se le exige a ningún adquirente confiado en la apariencia registral. 


\section{Bibliografía}

Asociación de Profesores de Derecho Civil (2018). Propuesta de Código Civil. Madrid: Tecnos.

Brancós Núñez, E. (2019). Una visión sesgada del artículo 34 de la Ley Hipotecaria. El notario del siglo XXI. Revista del Colegio Notarial de Madrid, 83, 48-55. Disponible en: https://bit.ly/2kmqkIP.

Castilla Barea, M. (2017). La obligación de alimentos como obligación familiar básica. En M. Yzquierdo Tolsada y M. Cuena Casas (dirs.). Tratado de Derecho de la Familia (vol. 1) (pp. 280-329). Cizur Menor (Navarra): Thomson Reuters-Aranzadi.

Cuena Casas, M. (1996). Reflexiones en torno a la venta de cosa ajena. Revista Crítica de Derecho Inmobiliario, 635, 1433-1478.

- (2008). La validez de la venta de cosa ajena como exigencia de sistema. NUL. Estudios Sobre Invalidez e Ineficacia, 1, 1.

- (2010). Doble venta: los efectos de la definitiva toma de partido del Tribunal Supremo. Revista Critica de Derecho Inmobiliario, 722, 2909-2947.

Domínguez Luelmo, A. (2016). Comentario del art. 34 LH. En A. Domínguez Luelmo (dir.). Comentarios a la Ley Hipotecaria (pp. 554-585). Cizur Menor (Navarra): Thomson Reuters-Aranzadi.

Domínguez Martínez, P. (2013). La compraventa como modelo de los contratos traslativos. En A. Carrasco Perera (dir.). Tratado de la Compraventa, Tomo I (pp. 51-61). Cizur Menor: Thomson Reuters-Aranzadi.

Estruch Estruch, J. (2016). Validez obligacional y posible eficacia real de la venta de cosa común por uno de los copropietarios. Revista Crítica de Derecho Inmobiliario, 755, 1229-1282.

Fernández Chacón, I. (2018). La transmisión de la propiedad en la compraventa. Cizur Menor (Navarra): Thomson Reuters-Aranzadi.

Fernández de Villavicencio Álvarez-Ossorio, C. (1994). Compraventa de cosa ajena. Barcelona: J. M. Bosch Editor.

García García, J. M. (1993). Derecho Inmobiliario Registral o Hipotecario. Tomo II (El concepto de tercero. Inoponibilidad. Fe pública. Prioridad). Madrid: Civitas.

García-Ripoll Montijano, M. (2015). Comentario a la Sentencia de 8 de octubre de 2014 (RJ 2014, 5784). Cuadernos Civitas de Jurisprudencia Civil, 98, 155-174. Disponible en: www.westlaw.es.

Goñi Rodríguez de Almeida, M. (2005). Sentencia del Tribunal Supremo de 20 de febrero de 2004. Revista Crítica de Derecho Inmobiliario, 1688, 643-648.

Herbosa Martínez, I. (2013). El contrato de compraventa civil. Madrid: Civitas. Disponible en: www.westlaw.es.

Juárez Torrejón, A. (2016). Temas de Derecho Inmobiliario Registral. Madrid: Tecnos.

López Frías, A. M. (2013). La venta de un inmueble común sin el consentimiento de todos los copropietarios. Revista Doctrinal Aranzadi Civil-Mercantil, 11, 63-88. Disponible en: www.westlaw.es. 
Méndez González, F. P. (2018). La «buena fe» del art. 34 de la Ley Hipotecaria. Una revisión crítica de la posición dominante en la doctrina y en la jurisprudencia. Revista Jurídica de Cataluña, 1, 9-40.

Moralejo Imbernón, N. (2013). El Registro de la Propiedad Inmobiliaria. En R. Bercovitz Rodríguez-Cano (coord.). Manual de Derechos Reales (pp. 103-121). Madrid: Bercal.

Moreno Martínez, J. A. (2013). Capítulo II. Del contrato de alimentos. Comentario de los arts. 1791 a 1797 CC. En R. Bercovitz Rodríguez-Cano (dir.). Comentarios al Código Civil. Tomo IX (pp. 12258-12318). Valencia: Tirant lo Blanch.

Murga Fernández, J. P. (2011). Venta de cosa ajena y publicidad registral. Revista de Derecho Patrimonial, 27, 319-329. Disponible en: www.westlaw.es.

Pérez Gurrea, R. (2012). Validez de la venta de la totalidad de una cosa común realizada por uno de los comuneros sin consentimiento de los demás: aplicación de la venta de cosa ajena a propósito de la Sentencia del Tribunal Supremo de 28 de marzo de 2012. Revista Crítica de Derecho Inmobiliario, 734, 3435-3666.

Pertínez Vílchez, F. (2012). Comentario a la Sentencia de 7 marzo 2012. Cuadernos Civitas de Jurisprudencia Civil, 90. Disponible en: www.westlaw.es.

Ragel Sánchez, L. F. (2012). La venta de cosa ajena: distinción de supuestos. En M. C. Gómez Laplaza (coord.). Cuestiones sobre la compraventa en el Código Civil. Principios europeos y Draft (pp. 45-88). Madrid: Edisofer.

- (2013). ¿En qué casos es inválida la venta de cosa ajena? En A. Carrasco Perera (dir.). Tratado de la Compraventa. Tomo I (pp. 871-884). Cizur Menor (Navarra): Thomson Reuters-Aranzadi.

- (2017). El régimen de gananciales. Cizur Menor (Navarra): Thomson Reuters-Aranzadi.

Toral Lara, E. (2019). El saneamiento por evicción en la compraventa y sus presupuestos. Cuadernos Civitas de Jurisprudencia Civil, 109, 279-312. Disponible en: www.westlaw.es.

Yzquierdo Tolsada, M. (2016). Comentario de la Sentencia del Tribunal Supremo de 15 de enero de 2013 (1153/2013). No vale la venta celebrada por un comunero sin contar con el resto de los partícipes, aunque sí valga la transmisión de las cuotas del vendedor. En M. Yzquierdo Tolsada (coord.) Comentarios a las sentencias de unificación de doctrina: civil y mercantil (vol. 6) (pp. 127-138). Madrid: Agencia Estatal Boletín Oficial del Estado; Dykinson.

Vela Sánchez, A. J. (2017). El régimen de gananciales. Cizur Menor (Navarra): Thomson Reuters-Aranzadi.

- (2019). Cesión de bien ganancial por un solo cónyuge a cambio de alimentos y principio de fe pública registral. A propósito de la STS, Sala $1^{\text {a }}$, de 29 de noviembre de 2018. Diario La Ley, 9364, 1-18. 